\title{
PVMapper: Report on the Second Public Opinion Survey
}

June 2013

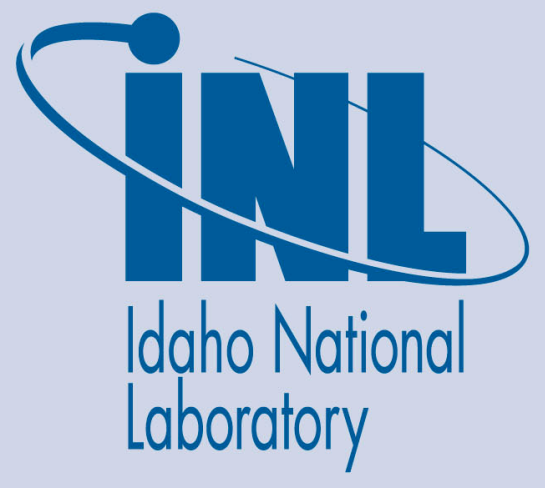

The INL is a U.S. Department of Energy National Laboratory operated by Battelle Energy Alliance 
INL/EXT-13-30706

\section{PVMapper: Report on the Second Public Opinion Survey}

June 2013

\section{Idaho National Laboratory \\ Idaho Falls, Idaho 83415}

http://www.inl.gov

Prepared for the

U.S. Department of Energy

Assistant Secretary for Energy Efficiency and Renewable Energy

Under DOE Idaho Operations Office

Contract DE-AC07-05ID14517 


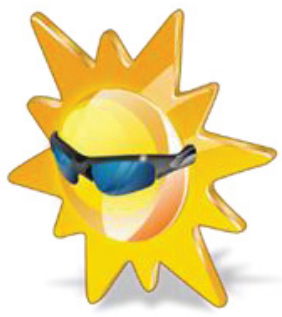

\section{PVMapper: Report on the Second Public Opinion Survey}

June 24, 2013

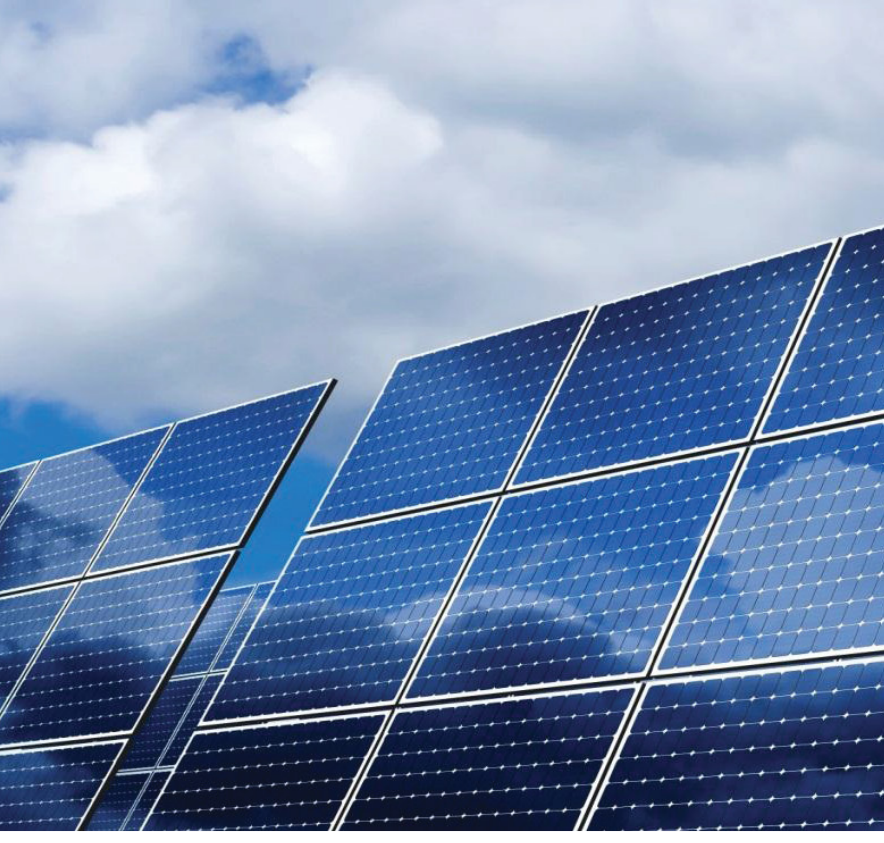

\section{$\boldsymbol{B}$}

BOISE STATE UNIVERSITY 


\section{Table of Contents}

List of Tables and Figures___ ii

Introduction__ 1

Findings in Brief __ 3

Survey Methodology ___ 4

Comparison to Census Data __ 6

Select Question Results___ 7

Q8. How strongly do you support or oppose the construction of large solar facilities in the U.S.?

Q4. Tell us whether you favor reducing, maintaining, or increasing U.S. production of the following electricity generation types \{Coal; Hydroelectric; Gas; Nuclear; Oil; Solar; and Wind\}.

Q5. How expensive do you think it is to produce electricity from each of the following resources?

Q12a-g. The next few questions have to do with placement of large-scale solar facilities.

For each of the following locations, how strongly would you support or oppose construction of a large-solar facility?

Q13. Of all of the following land types, which one would you MOST PREFER to be selected for siting a large-scale solar facility?

Q14-21. How much buffer distance is acceptable between a large solar facility and \{ a residential area; existing agricultural land; an area of cultural or historical importance; an area used as a migration route by wildlife; an area used as nesting sites or breeding grounds by wildlife; recreation areas such as hunting, fishing, or hiking locations; wetlands; or an existing large solar facility\}?

Next Steps 15

Acknowledgement 16

Disclaimer 16

Appendix A: Southwestern Oversample (Southern California) Frequencies 17

Appendix B: National Frequencies 31 


\section{List of Tables and Figures}

TABLE 1: COMPARISON OF WEIGHTED SAMPLE ESTIMATES TO 2007-2011 ACS AGE ESTIMATES

TABLE 2: COMPARISON OF WEIGHTED SAMPLE ESTIMATES TO 2007-2011 ACS EDUCATIONAL ATTAINMENT FOR

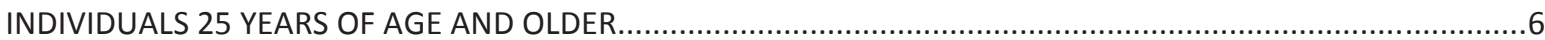

FIGURE 1: ATTITUDES TOWARDS CONSTRUCTION OF UTILITY-SCALE SOLAR FACILITIES .......................................7

FIGURE 2: TELL US WHETHER YOU FAVOR REDUCING, MAINTAINING, OR INCREASING U.S. PRODUCTION OF THE FOLLOWING ELECTRICITY GENERATION TYPES?

FIGURE 3: HOW EXPENSIVE DO YOU THINK IT IS TO PRODUCE ELECTRICITY FROM EACH OF THE FOLLOWING RESOURCES?

FIGURE 4: SUPPORT AND OPPOSITION FOR UTILITY SCALE PV SOLAR CONSTRUCTION BASED ON LAND TYPE........10

FIGURE 5: 2012 SURVEY RESPONDENTS' MOST PREFERRED SITING LOCATIONS, BY LAND TYPE ............................11

FIGURE 6: PREFERRED LAND TYPES FOR SITING LARGE-SCALE SOLAR FACILITIES, 2013........................................12

FIGURE 7: ATTITUDES TOWARDS CONSTRUCTION OF SOLAR FACILITIES WITHIN RESPONDENTS' COUNTIES ..........12

FIGURE 8: PERCENTAGE OF 2012 NATIONAL AND SOUTHWESTERN RESPONDENTS COMFORTABLE WITH BUFFER

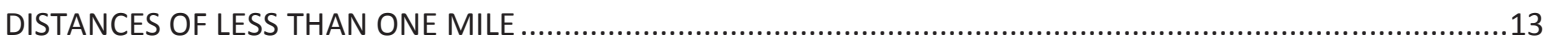




\section{Introduction}

This report has been developed as an integral part of the PVMapper project, funded by the U.S. Department of Energy's Office of Energy Efficiency and Renewable Energy's SunShot program. The objective of the SunShot program is to reduce the total costs of solar energy systems. The scope of PVMapper is to develop a geographic information system (GIS) based project planning tool to identify optimal utility-scale solar facility sites. The specific objectives of the project are to 1 ) develop the software on an open-source platform; 2) integrate the appropriate data sets and GIS layers; 3) include a measure of social risk and public acceptance; 4) enable customization of variable weights; 5) provide a free and accessible platform for software download; and 6) provide a sustainability plan to ensure future relevance of the software. When completed, PVMapper is intended to be used by solar developers, Authorities Having Jurisdiction (AHJs), and other interested parties. This project supports SunShot's objective by reducing the non-hardware balance of system costs ("soft costs") for utility-scale solar project development.

In order to accomplish the third project objective - including a measure of social risk and public acceptance within PVMapper - the project team has developed a time-series public opinion survey, administered yearly over the course of the three-year project. This report highlights the results and preliminary analyses from the second survey in this series. While the results of this survey are valuable to both PVMapper and future utility-scale solar development, the time-series design is extremely important. The completion of the series enables the extension of the dataset to much richer information. For example, the research team altered this iteration to sharpen the focus on specific topics (those posing potentially higher risks) and target specific locations in the oversample (such as communities near existing facilities). Using similar approaches for each iteration leads to an increasingly greater amount of detail regarding siting risks. The need for this extended dataset to aid in siting utility-scale solar projects is evident, as developers continue to scale back initial plans due to unidentified or incorrectly quantified social risks. It should be noted that this report provides the complete dataset from the survey, encompassing the wide-ranging responses from all of the survey questions. Although the methods used to integrate these data into PVMapper's siting algorithms is not the purpose of this report, allusions to integration can be found in the discussions surrounding the design of questions and types of data to be used.

The next few sections of the report are assembled for navigability. First, a Findings in Brief section discusses the most important results, focusing on commonalities and trends with the previous year's survey while the subsequent sections of the report focus on the results of the Southwest oversample of residents nearby existing projects or those under construction. Next, the Survey Methodology section 
provides an overview of the survey, to include descriptions of the survey design, sample populations, and survey process. The third section compares our oversample population to census data, to demonstrate potential differences and highlight needs for further inquiry. The fourth section, Select Question Results, provides preliminary findings to some of the more interesting and important sets of responses to specific survey questions. Specific questions chosen for initial analysis are those relating to development preferences by land-use types, the magnitude of potential risk, and geospatial preferences to specific land characteristics. Finally, the Next Steps section of the report identifies opportunities for further, and more in-depth, analyses based on these data and preliminary findings. 


\section{Findings in Brief}

The most important finding for the two surveys is the consistency of respondents' preferences for the topographical characteristics and uses for land where they prefer or oppose utility-scale solar projects to be sited. This pattern or "shape" of responses holds true when different lands and their uses are rated in comparison to each other. Furthermore, the shape and preferences for facility placement are consistent regardless of whether buffer distances are provided in the survey questions or respondents are asked to provide their own distance preferences for certain land uses. Generally speaking, respondents favor facilities to be constructed and operated on lands that were once used for industrial purposes (mining, contaminated lands, former industrial), military bases, and undeveloped public lands. To a lesser degree they support facilities on undeveloped privately owned land. Respondents clearly oppose facilities on environmentally sensitive land, agriculturally productive land, as well as property with cultural and historical significance. Furthermore, survey respondents have strong reservations about placing solar facilities proximate to environmentally valuable or culturally and historically significant lands. This finding is very important for the development of PVMapper because land uses and types are readily mappable and available in datasets, and project developers will have the ability to generally apply social preferences for siting to specific locations based on land attributes.

Both of the surveys to date find very strong support for large-scale solar power generation facilities in the abstract as well as siting in a non-specific but localized location such as a county. Respondents feel it is very important for developers and utilities to maintain trust with population in regard to sharing information readily and providing opportunities for public input for specific projects. There is ample opportunity for developers, utilities, and authorities having jurisdiction for educating the public in regard to specific power generation technologies. This is illustrated by the relatively high initial survey response refusal rate from the first year ${ }^{1}$, the aggregate responses from the second year that were not particularly accurate in regard to the cost of different technologies, and the buffer distances respondents' chose when given an open-ended opportunity to answer a question rather than being supplied pre-defined ranges of distance by the survey team.

\footnotetext{
${ }^{1}$ In the test survey script respondents were initially told the survey would investigate large-scale solar power facilities and a number refused citing lack of familiarity with the subject.
} 


\section{Survey Methodology}

The survey instrument was designed by researchers at Idaho State University, Boise State University, and Idaho National Laboratory, and the Social Science Research Unit (SSRU) at the University of Idaho. The survey and frequency results are presented as Appendices A (Southwestern oversample) and B (National sample). The study was approved for human subjects research by the University of Idaho Institutional Review Board (IRB), protocol number 12-089, as well as by the IRBs of all other institutions collaborating on this research. All interviewers completed an online National Institutes of Health training course in human subjects research in addition to training in survey data collection procedures and telephone etiquette. Interviewers were monitored during each calling session by trained supervisors.

Similar to the previous year's survey, this year's survey was administered to two sample populations, a national sample and a Southwestern oversample. However, this iteration narrowed the oversample population to six counties in Southern California. In fact, these counties were chosen because of their close proximity to proposed, developing, or existing utility-scale solar generation facilities. That is, the goal behind this year's oversampling decision was to collect public opinion data from people who are more likely to have firsthand experience with utility-scale solar. Based on data from the Solar Energy Industries Association ${ }^{2}$, there is a considerable amount of solar development activity occurring in Southern California. By focusing the oversample on respondents who are geographically closer to active utility-scale development, construction, and operation, the survey is able to collect opinions from respondents that are more likely to be based on direct personal experiences with these facilities.

Survey data were collected on Wincati ${ }^{3}$ telephone interviewing software. On average, the survey took 18 minutes to complete. For the Southwestern oversample (Southern California), calls began in March 2013 and continued until June 2013; for the national sample, calls began February 2013 and continued until June 2013. The SSRU employed a Spanish-language speaking interviewer.

Survey weights were calculated to account for the complex survey design using SAS, Version $9.2^{4}$. Survey weights account for the fact that different households had different probabilities of selection for the study depending on whether a household had only wireless telephone(s), only landline telephone(s), or both wireless and landline telephones. Weighted frequencies, percentages, and standard errors were calculated using SAS.

\footnotetext{
${ }^{2}$ http://www.seia.org/research-resources/major-solar-projects-list

${ }^{3}$ Wincati, v 5.0. 2012. Sawtooth Technologies, Inc. Northbrook, IL.

${ }^{4}$ SAS, Version 9.2. 2009. SAS Institute, Inc. Cary, N.C
} 


\section{National Sample}

This study used a dual-frame telephone survey methodology, utilizing both household Random Digit Dialing (RDD) landline numbers $(n=2,929)$ and wireless RDD telephone numbers $(n=3,000)$. Both frames were simple random samples of numbers from within the United States.

In total, 429 interviews were completed, with 10 interviews completed in Spanish. The final combined response rate $\left(\operatorname{AAPOR} 2^{5}\right.$ ) for the two frames is 10.4 percent, the final cooperation rate is 28.8 percent, and the final refusal rate is 25.7 percent.

\section{Southwestern Oversample (Southern California)}

This study used a dual-frame telephone survey methodology, utilizing household RDD landline numbers $(n=5,442)$ and wireless RDD telephone numbers $(n=5,000)$. Both frames were simple random samples of numbers from within six counties in southern California (Inyo, Kern, Riverside, San Bernardino, San Luis Obispo, and Ventura).

In total, 695 interviews were completed, with 82 interviews completed in Spanish. The final combined response rate (AAPOR2) for the two frames is 9.7 percent, the final cooperation rate is 27.7 percent, and the final refusal rate is 27.1 percent. Heavy fires with evacuations were reported in some of the counties in early May while this study was underway.

\footnotetext{
${ }^{5}$ American Association of Public Opinion Research. 2011. Standard Definitions: Final Disposition of Case Codes and Outcome Rates for Surveys. Available at:

http://www.aapor.org/AM/Template.cfm?Section=Standard Definitions2\&Template=/CM/ContentDisplay.cfm\&C ontentID=3156
} 


\section{Comparison to Census Data}

Table 1 shows a comparison between the age distribution of respondents in this study's oversample population and recent Census Bureau estimates of the adult population in the same six counties ${ }^{6}$. Similarly, Table 2 displays the comparison between the educational attainment of respondents in this study's oversample population and recent Census Bureau estimates for individuals 25 years of age or older in the same six counties. Our oversample tended to be older and more highly educated than the general population of these six counties in Southern California, and subsequent analysis will determine to what extent, if any, the results are biased as a result.

Table 1: Comparison of Weighted Sample Estimates to 2007-2011 ACS Age Estimates

\begin{tabular}{|c|c|c|c|}
\hline Age Category & ACS & $\begin{array}{l}\text { This } \\
\text { Study }\end{array}$ & $95 \%$ Confidence Limits \\
\hline $18-19$ years old & $4.9 \%$ & $1.7 \%$ & $0.6 \%-2.8 \%$ \\
\hline $20-24$ years old & $11.0 \%$ & $8.6 \%$ & $5.5 \%-11.7 \%$ \\
\hline $25-34$ years old & $19.6 \%$ & $13.8 \%$ & $10.2 \%-17.4 \%$ \\
\hline $35-44$ years old & $19.8 \%$ & $13.4 \%$ & $10.1 \%-16.6 \%$ \\
\hline $45-54$ years old & $19.9 \%$ & $17.1 \%$ & $14.0 \%-20.3 \%$ \\
\hline $55-59$ years old & $7.9 \%$ & $12.9 \%$ & $9.8 \%-16.1 \%$ \\
\hline $60-64$ years old & $6.5 \%$ & $6.9 \%$ & $4.6 \%-9.3 \%$ \\
\hline $65-74$ years old & $8.4 \%$ & $14.8 \%$ & $11.8 \%-17.8 \%$ \\
\hline $75-84$ years old & $5.1 \%$ & $8.6 \%$ & $6.3 \%-10.9 \%$ \\
\hline Over 85 years old & $1.9 \%$ & $2.1 \%$ & $1.1 \%-3.2 \%$ \\
\hline
\end{tabular}

Table 2: Comparison of Weighted Sample Estimates to 2007-2011 ACS Educational Attainment for Individuals 25 Years of Age and Older

\begin{tabular}{|c|c|c|c|c|}
\hline Education & ACS & This Study & Lower $95 \% \mathrm{CL}$ & Upper $95 \%$ CL \\
\hline Eight grade or less & $10.3 \%$ & $6.5 \%$ & $3.9 \%$ & $9.1 \%$ \\
\hline $9^{\text {th }}-12^{\text {th }}$ grade, no diploma & $11.0 \%$ & $8.0 \%$ & $5.2 \%$ & $10.8 \%$ \\
\hline High school graduate/GED & $25.0 \%$ & $13.0 \%$ & $9.8 \%$ & $16.3 \%$ \\
\hline Some college (no degree) & $24.7 \%$ & $24.7 \%$ & $20.6 \%$ & $28.8 \%$ \\
\hline Associates' degree & $7.9 \%$ & $9.1 \%$ & $6.4 \%$ & $11.9 \%$ \\
\hline Bachelor's degree & $13.6 \%$ & $22.0 \%$ & $18.1 \%$ & $26.0 \%$ \\
\hline Graduate or professional degree & $7.5 \%$ & $16.6 \%$ & $13.2 \%$ & $20.0 \%$ \\
\hline
\end{tabular}

\footnotetext{
${ }^{6}$ 2006-2010 American Community Survey 5-Year Estimates
} 


\section{Select Question Results}

Local opposition in the solar-siting process is an area of great concern for solar developers. The degree of support a solar project enjoys in any given community can greatly affect the speed and efficiency of the permitting and siting processes. This section highlights the results of many of the survey items, and at the same time provides insight into how the data are expected to be used by PVMapper. The analyses provided herein utilize data collected from the Southwest oversample. As described previously, the Southwest oversample includes six contiguous counties in Southern California.

Q8. How strongly do you support or oppose the construction of large solar facilities in the U.S.? Our survey included this question to get an idea of the degree of support and opposition to the construction of solar facilities by respondents from this southern Californian population. The results of this over-sample of six counties in southern California reflected high levels of general support for solar development in the U.S. The results from this question were based on a five-point Likert scale ${ }^{7}$, ranging from strongly support to strongly oppose. For simplicity, respondents' levels of support and opposition have been grouped together. Figure 1 shows that total support for constructing solar facilities in the U.S. was extremely high at $81.6 \%$. Further, total opposition to developing solar facilities in the U.S. was extremely low (5.4\%). Respondents who neither supported nor opposed solar construction was also low

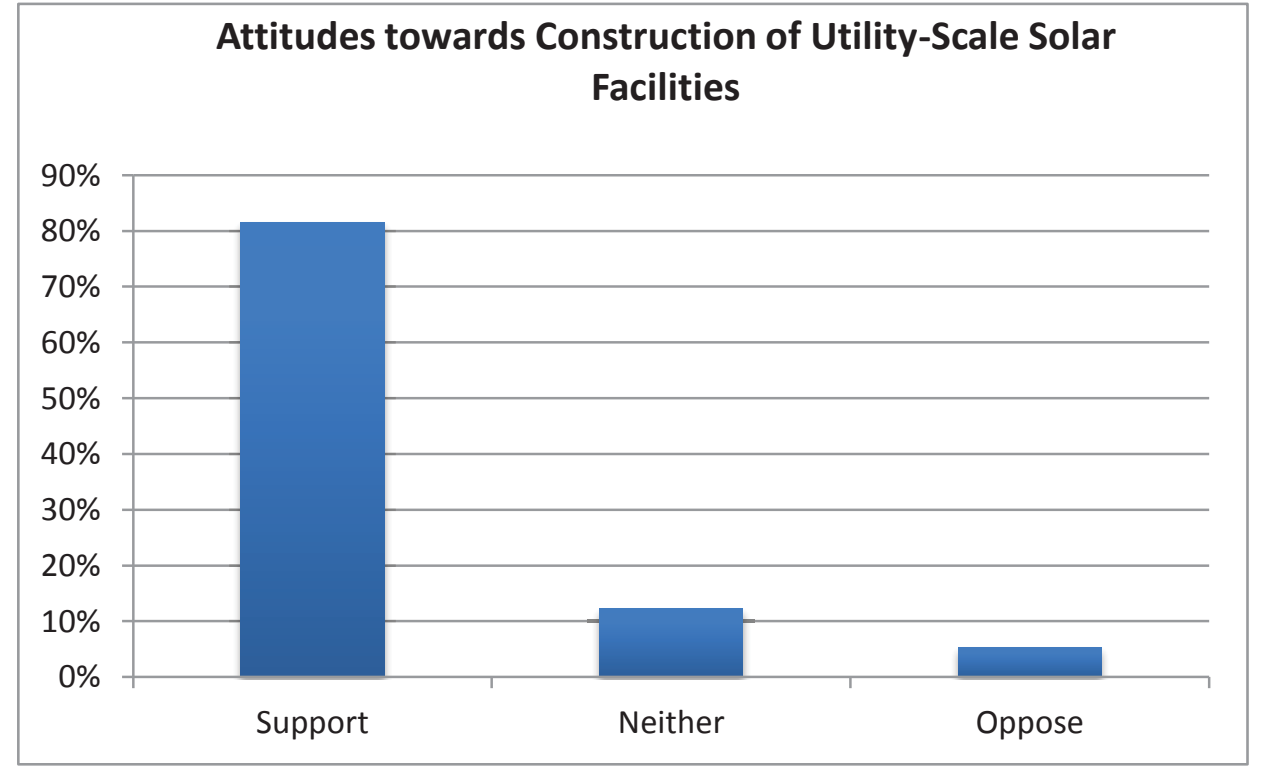

Figure 1: Attitudes towards Construction of Utility-Scale Solar Facilities
$(12.3 \%)$, while respondents who did not know $(0.8 \%)$ and are not included on the graph.

Thus, the respondents in the oversample overwhelmingly support the construction of new solar facilities in the U.S., a result that is positive given that all of the respondents are located near a proposed, existing, or developing solar facility.

\footnotetext{
${ }^{7} 1$ (strongly support); 2 (somewhat support); 3 (neither support nor oppose); 4 (somewhat oppose); 5 (strongly oppose)
} 
Q4. Tell us whether you favor reducing, maintaining, or increasing U.S. production of the following electricity generation types \{Coal; Hydroelectric; Gas; Nuclear; Oil; Solar; and Wind\}.

Figure 2 shows whether respondents favor increasing, maintaining, or reducing U.S. production of electricity from a variety of resource types, including coal, hydroelectric, natural gas, nuclear, oil, solar, and wind. Overall, our sample of Southern Californian respondents overwhelmingly supports (over $80 \%$ ) increasing electricity generated from both solar and wind resources. Additionally, a greater proportion of respondents favor increasing the production of electricity from hydroelectric (50\%) and natural gas (45\%) facilities. For the remaining three resource types-coal, nuclear, and oil-a greater proportion of respondents favors reducing (50\%) electric power generated rather than maintaining $(20 \%)$ or increasing (15-25\%) current generation levels from these resources. Smaller proportions of respondents favor increasing electricity generated from coal (15\%), nuclear (25\%), and oil (25\%). Overall, our data demonstrate that Southern Californian respondents favor increasing electricity generated from renewable resources.

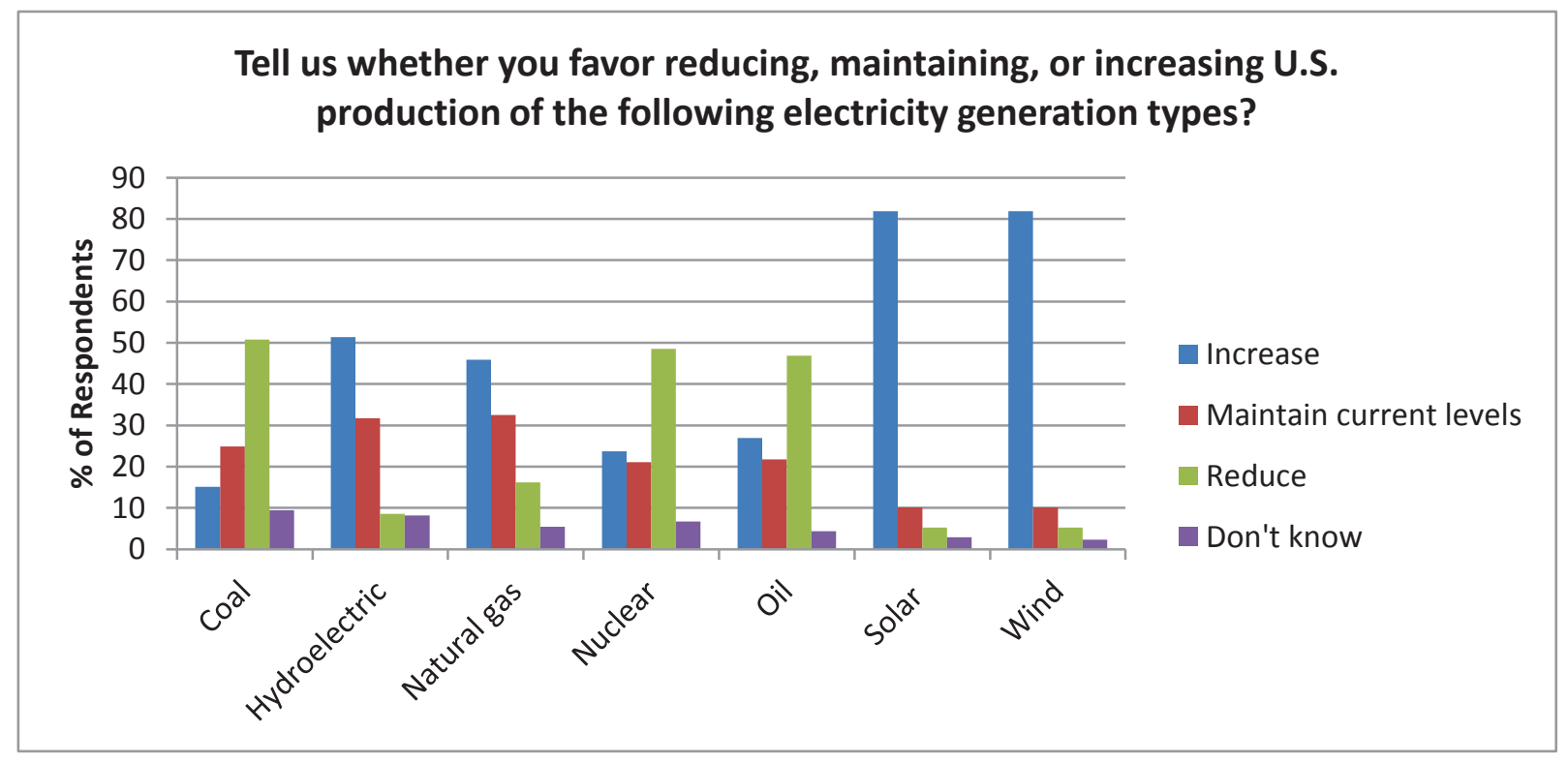

Figure 2: Tell us whether you favor reducing, maintaining, or increasing U.S. production of the following electricity generation types?

Q5. How expensive do you think it is to produce electricity from each of the following resources?

In Figure 3, we compare respondents' perceptions of the cost of electricity generated from different resource types-coal, hydroelectric, natural gas, nuclear, oil, solar, and wind. An overwhelming proportion of respondents thinks that electric power generation from nuclear and oil resources is expensive. In particular, $60 \%$ of respondents believe that electricity generated from nuclear energy is expensive, and $65 \%$ of respondents believe that electricity generated from oil is expensive. As well, nearly $40 \%$ of respondents consider electricity generated from both hydroelectric and solar resources to 


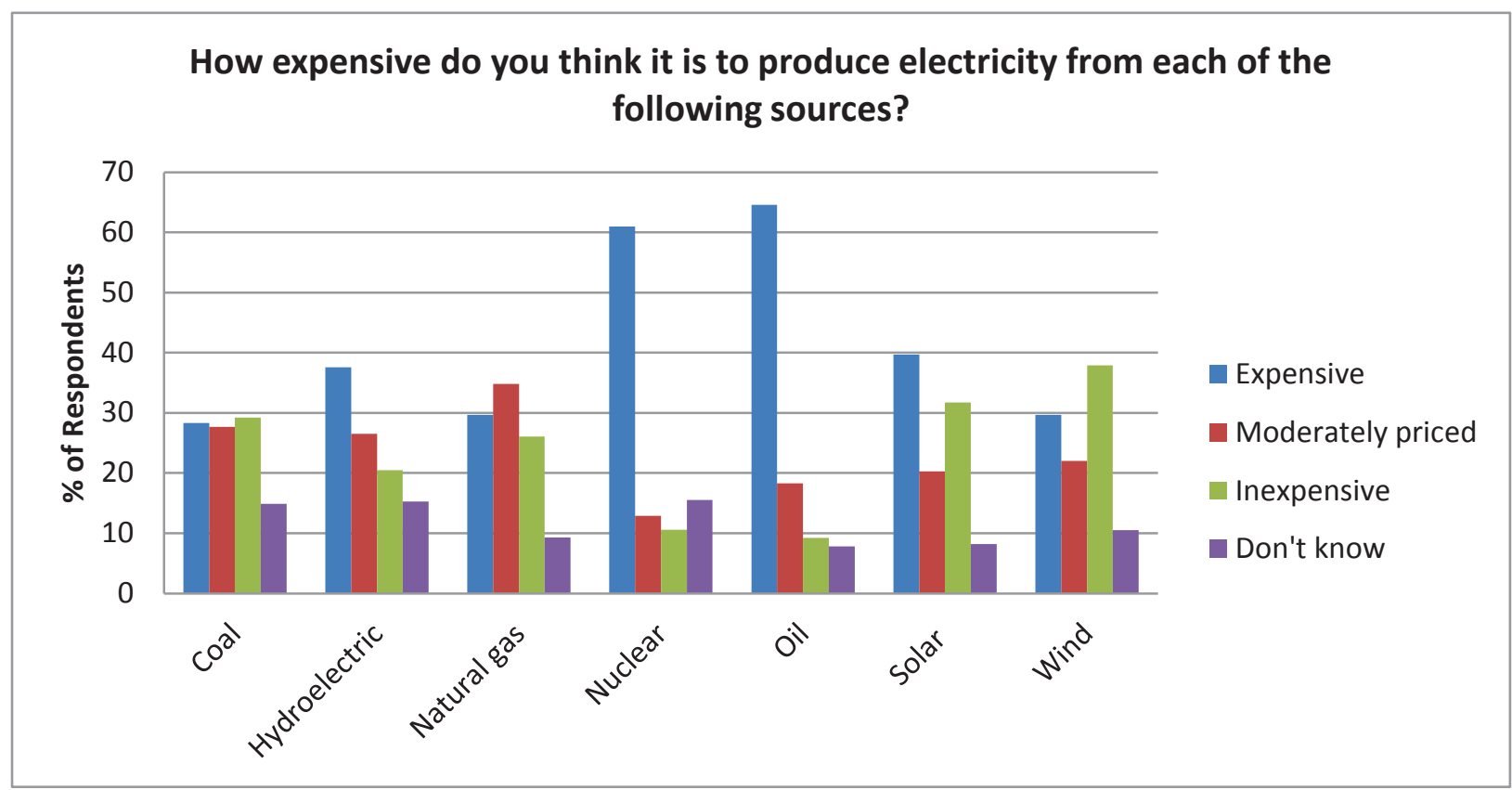

Figure 3: How expensive do you think it is to produce electricity from each of the following resources?

be expensive, versus $20 \%$ and $30 \%$ (respectively) who consider it inexpensive. In contrast, respondents are evenly divided regarding whether electricity derived from coal is expensive (30\%) or inexpensive (30\%). Finally, a greater proportion of respondents considers electricity derived from wind inexpensive to produce (nearly $40 \%$ ) than consider it expensive to produce (nearly $30 \%$ ).

Q12a-g. The next few questions have to do with placement of large-scale solar facilities. For each of the following locations, how strongly would you support or oppose construction of a large-solar facility? Utility-scale or large-scale solar photovoltaic (PV) technology is land use-intensive, and thus it was of interest to examine how strongly the public supported and opposed solar construction on various land types. This question was designed to solicit information that can be used to inform the geospatial data in PVMapper in order to help prioritize land selection for solar development, because topographical characteristics, such as how a given parcel of land is currently being used, are included in PVMapper as data layers. 


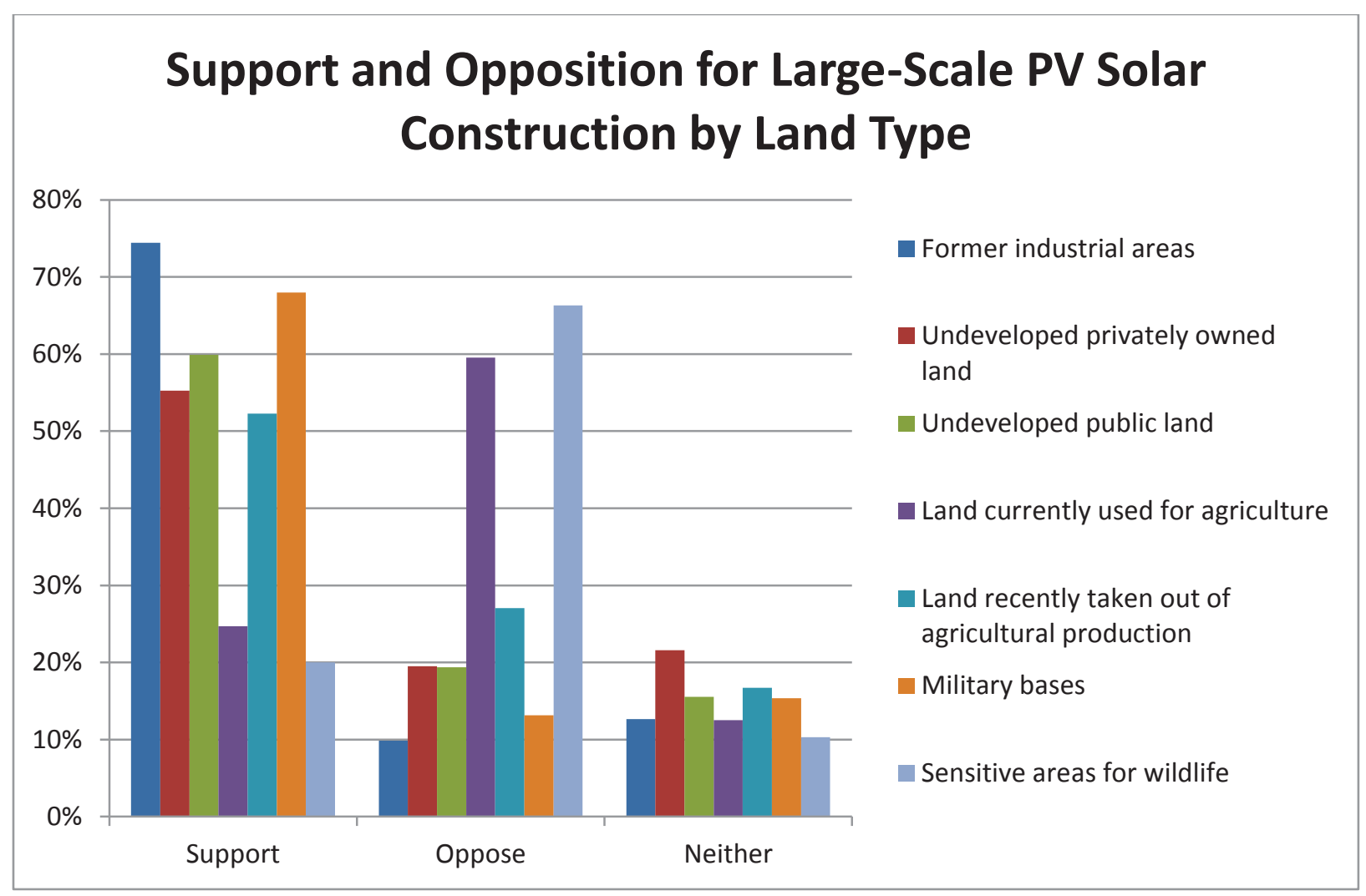

Figure 4: Support and Opposition for Utility Scale PV Solar Construction based on Land Type

The questions focused on seven land types in the 2013 survey, asking respondents about each type in separate questions. The same 5-point Likert scale described for Q8 was used for these questions, and respondents' levels of support and opposition have been grouped together. The results in Figure 4 show that large percentages of the respondents supported, and few respondents opposed, large-scale solar facilities being built on former industrial areas, military bases, and undeveloped public lands. This same pattern of findings was also true for land recently taken out of agricultural production and undeveloped privately-owned land. Alternatively, a high percentage of the respondents opposed, and very few respondents supported, large-scale solar facilities being built on sensitive areas for wildlife and land currently used for agriculture. "Don't know" responses ranged from 3-5\% across the seven different land types, and are not included on the graph.

Q13. Of all of the following land types, which one would you MOST PREFER to be selected for siting a large-scale solar facility?

In 2012, when asked what type of land they would most prefer a utility-scale solar facility to be sited, respondents from both the National and Southwest samples preferred contaminated land, former industrial land, and former mining land (Figure 5). Very few respondents from either sample prefer red pristine land or even former agricultural land from among the choices presented. 


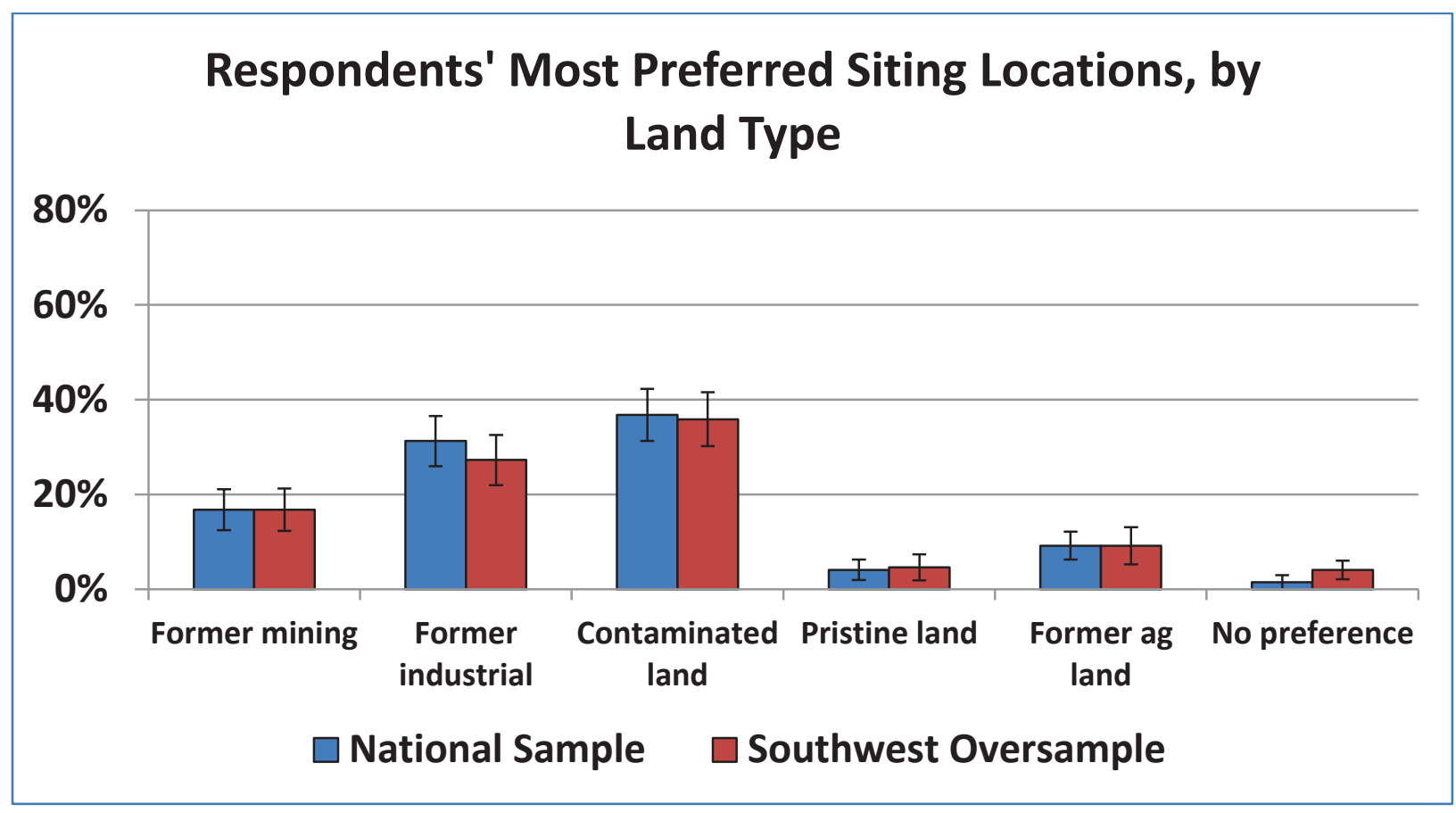

Figure 5: 2012 Survey Respondents' Most Preferred Siting Locations, by Land Type

For the 2013 survey, the question was again designed to solicit information that can be used to inform the geospatial data in PVMapper to help prioritize land selection for solar development. Grouping the same seven land types (from Question 12) together into one question, we asked respondents which one they would most prefer to be selected for siting a large-scale solar facility. Figure 6 depicts the relative distribution of respondents' preferences. Survey respondents indicated that former industrial areas (34\%), undeveloped public land (18\%), and military bases (18\%) were the more preferred land types for siting solar facilities. Land types that very few respondents preferred included: sensitive areas for wildlife $(0 \%)$, land currently used for agriculture $(1 \%)$, undeveloped privately owned land $(8 \%)$, and land recently taken out of agricultural production (8\%). $12 \%$ of respondents had no preference for land type, and $1 \%$ reported they did not know. We infer from these data that developers of large-scale solar facilities may encounter some public opposition if the facility is going to be built in sensitive areas, on land currently used for agriculture, and land formerly used for agriculture, and would likely receive some support if the facility is going to be built in former industrial areas. These survey results show which land types are more preferred by the public, and can be used to inform which locations considered for development are more or, by inference, less preferred by the public. 


\title{
Preferred Land Types for Solar Facilities
}

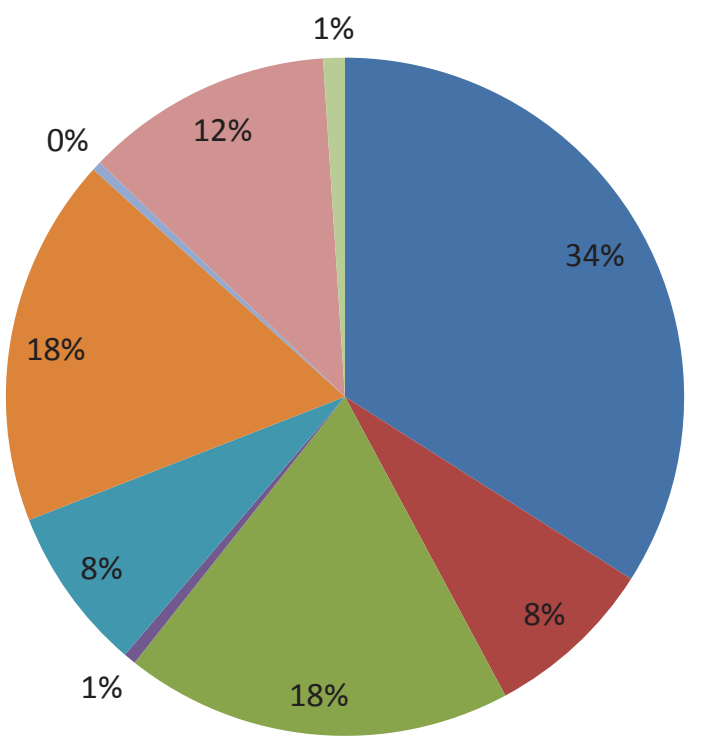

\author{
Former industrial areas \\ - Undeveloped privately owned \\ land \\ - Undeveloped public land \\ - Land currently used for \\ agriculture \\ - Land recently taken out of \\ agricultural production \\ Military bases \\ Sensitive areas for wildlife \\ No preference \\ Don't know
}

Figure 6: Preferred Land Types for Siting Large-Scale Solar Facilities, 2013

Q9. Suppose the construction of a large solar facility was planned near your residence. How strongly would you support or oppose its construction?

Based on literature that researches the relationship between elements of place-attachment and support for renewable energy construction projects, we included a question to gauge the degree to which respondents would support or oppose a solar facility being built within their counties. Similar to previous

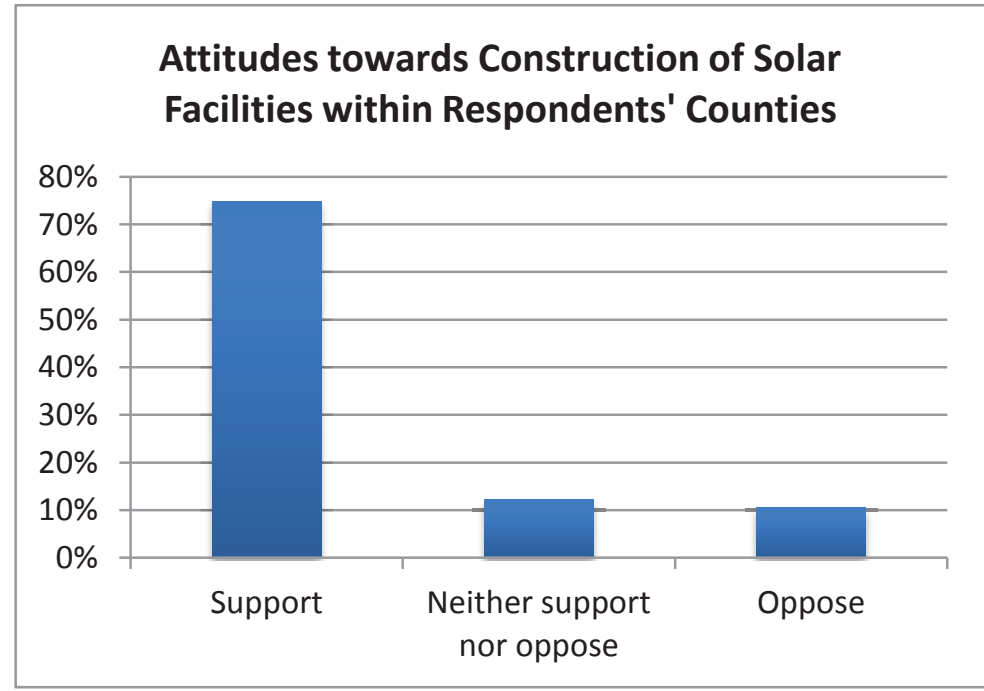

Figure 7: Attitudes towards Construction of Solar Facilities within Respondents' Counties questions, levels of support or opposition were gauged on a five-point Likert scale ranging from strongly support to strongly oppose. Again, we condensed the levels of support and opposition into two categories from four to simplify the chart. Looking at the data provided in Figure 7, support for solar in one's county is very high (74.8\%). Further, opposition (10.5\%) to the construction of solar facilities in the respondents' county is very low. 
Respondents who neither supported nor opposed the idea of a solar facility being sited in their county were also minimal (12.2\%). Those who did not know (2.5\%) are not included in the graphic. Support for solar construction dropped $6.8 \%$ and opposition rose $5.1 \%$ between general support for solar construction (see Figure 1) and support for solar developments in one's own county. Despite this diminished support, respondents were still overwhelmingly supportive of solar construction if it occurred in their respective counties. These results indicate a strong preference towards solar developments, even if the construction takes place within one's county. However, later in the survey a fair number of respondents chose self-defined, outsized buffer distances for solar facilities from certain types of lands and uses. In many cases these buffers would place the facilities outside of the county. This is an important consideration for developers, implying that specific land use and siting location may be more important than supporting a "local" facility for many respondents.

Q14-21. How much buffer distance is acceptable between a large solar facility and a residential area; existing agricultural land; an area of cultural or historical importance; an area used as a migration route by wildlife; an area used as nesting sites or breeding grounds by wildlife; recreation areas such as hunting, fishing, or hiking locations; wetlands; or an existing large solar facility\}?

Given that large-scale solar facilities are land use-intensive, and that one concern among some members of the public is the effect these facilities might have on other existing features of the physical environment, the 2013 survey asked respondents what the acceptable buffer distance is between a large solar facility and other physical features. These questions in particular are highly relevant to PVMapper in that the results can be used to help determine the degree to which a proposed facility has an acceptable buffer distance between its location and other topographical features of importance.

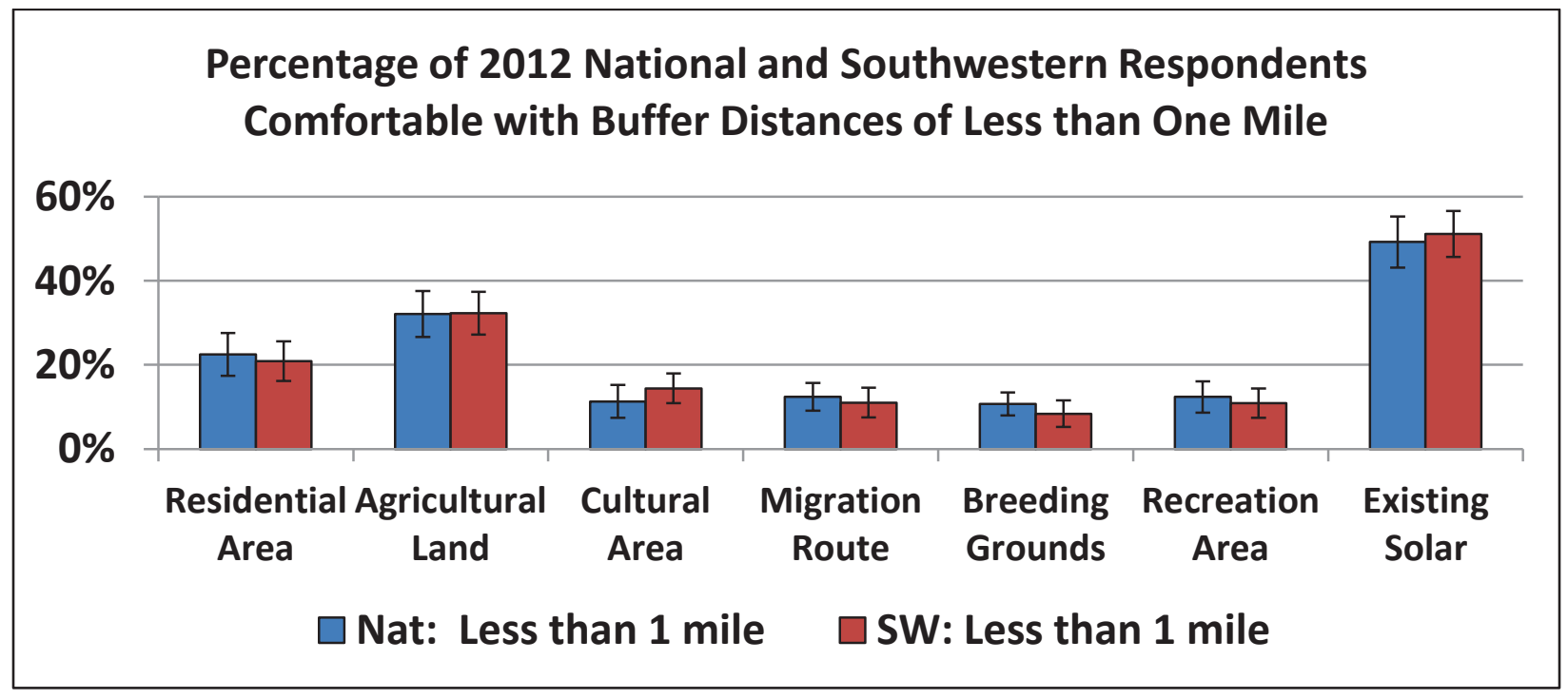

Figure 8: Percentage of 2012 National and Southwestern Respondents Comfortable with Buffer Distances of Less than One Mile 
In the 2012 surveys, respondents were asked what distance they felt was an appropriate buffer distance between a solar panel facility and each of seven areas. The response categories were less than one mile, between one and five miles, between six and ten miles, and more than ten miles. Looking at the results in Figure 8, the shortest buffer distances were preferred between a utility scale solar facility and an existing such facility, with nearly half of respondents from both the southwest and national samples stating that less than a mile was an appropriate distance. In addition, respondents were more comfortable with buffers of less than a mile between agricultural land and residential areas and a solar facility, but very few respondents felt that less than a mile was an appropriate buffer between areas of cultural or historical importance, wildlife migration routes, wildlife breeding grounds, and recreation areas.

In 2013, the question about appropriate buffer distances was changed so that respondents could name any distance; all measurements were converted to miles for the purpose of analysis. The pattern of responses was the same as in 2012, with respondents preferring larger buffers between solar facilities and wildlife migration routes, breeding grounds for wildlife, recreation areas, wetlands, and existing solar facilities. Respondents were more comfortable with small buffers between solar facilities and residential areas or agricultural areas. 


\section{Next Steps}

Further analysis is planned to examine the very large support for solar in the abstract, the support for solar facilities to be placed within the county, and the seemingly contradictory self-selected distances for buffer zones. In scholarly literature this is frequently observed and commonly referred to as the "social gap." The team has extensively tested a number of models for two siting buffers, agriculture and wildlife, which indicates a low correlation for almost all demographic factors and buffer distances. Based on the results, siting preferences seem to be tied more strongly to the land use itself rather than more commonly cited factors such as ideology, political party, education level, and belief in climate change to correlate with solar development. This finding strengthens PVMapper and the efficacy of incorporating social risk as part of the tool because the social preferences are not tied to specific demographics that may be applied to only some locations and populations. More analysis needs to be done for confirmation.

The survey team is already weighing different approaches for questions and buffer distances to the final time-series survey. Options under consideration include altering wording to reconfirm the pattern and shape of respondent preferences, supplying respondents with specific and refined sets of buffer distances that originate from a survey of actual buffer distances in existing projects, selecting a different state for the oversample, and expanding analysis and the suite of questions for the national sample. 


\section{Acknowledgement}

This material is based upon work supported by the Department of Energy's Office of Energy Efficiency and Renewable Energy under Award Number DE-EE0005351.

\section{Disclaimer}

This report was prepared as an account of work sponsored by an agency of the United States

Government. Neither the United States Government nor any agency thereof, nor any of their employees, makes any warranty, express or implied, or assumes any legal liability or responsibility for the accuracy, completeness, or usefulness of any information, apparatus, product, or process disclosed, or represents that its use would not infringe privately owned rights. Reference herein to any specific commercial product, process, or service by trade name, trademark, manufacturer, or otherwise does not necessarily constitute or imply its endorsement, recommendation, or favoring by the United States Government or any agency thereof. The views and opinions of authors expressed herein do not necessarily state or reflect those of the United States Government or any agency thereof. 
Appendix A: Southwestern Oversample (Southern California) Frequencies

\begin{tabular}{|c|c|c|c|c|}
\hline Question & Responses & $\begin{array}{c}\text { Raw } \\
\text { Frequency }\end{array}$ & $\begin{array}{c}\text { Weighted } \\
\text { Percent }\end{array}$ & $\begin{array}{l}\text { Std. } \\
\text { Error }\end{array}$ \\
\hline $\begin{array}{r}\text { Q1. Which of the following } \\
\text { statements best describes how } \\
\text { closely you follow energy } \\
\text { issues? } \\
(\mathrm{n}=695)\end{array}$ & $\begin{array}{r}\text { You follow energy issues very closely } \\
\text { You sometimes pay attention to energy issues } \\
\text { You rarely pay attention to energy issues } \\
\text { You never pay attention to energy issues } \\
\text { Don't know }\end{array}$ & $\begin{array}{r}214 \\
357 \\
94 \\
28 \\
2\end{array}$ & $\begin{array}{r}30.3 \% \\
49.4 \% \\
15.7 \% \\
3.9 \% \\
0.7 \% \\
\end{array}$ & $\begin{array}{l}2.0 \% \\
2.2 \% \\
1.7 \% \\
0.8 \% \\
0.5 \%\end{array}$ \\
\hline $\begin{array}{l}\text { Q2. Where do you get most of } \\
\text { your information about energy? } \\
\qquad(\mathrm{n}=627)\end{array}$ & $\begin{array}{r}\text { Newspaper (print or online) } \\
\text { Magazine(s) } \\
\text { Books } \\
\text { Friends } \\
\text { The Internet } \\
\text { An organization or interest group } \\
\text { TV news (please specify) } \\
\text { TV documentaries } \\
\text { Other source (please specify) } \\
\text { Don't know }\end{array}$ & $\begin{array}{r}149 \\
21 \\
7 \\
21 \\
186 \\
13 \\
190 \\
33 \\
6 \\
1\end{array}$ & $\begin{array}{r}24.4 \% \\
3.2 \% \\
1.1 \% \\
3.3 \% \\
29.6 \% \\
1.8 \% \\
30.4 \% \\
5.3 \% \\
0.8 \% \\
0.1 \% \\
\end{array}$ & $\begin{array}{l}2.0 \% \\
0.8 \% \\
0.5 \% \\
0.8 \% \\
2.1 \% \\
0.6 \% \\
2.1 \% \\
1.0 \% \\
0.4 \% \\
0.1 \% \\
\end{array}$ \\
\hline $\begin{array}{r}\text { Q3. In considering energy } \\
\text { sources, which of the following } \\
\text { factors are most important to } \\
\text { you? } \\
(\mathrm{n}=695)\end{array}$ & $\begin{array}{r}\text { Cost } \\
\text { Reliability } \\
\text { Safety } \\
\text { Whether or not it is produced domestically/locally } \\
\text { Job opportunities } \\
\text { Whether or not it is renewable } \\
\text { Environmental impacts } \\
\text { Other }\end{array}$ & $\begin{array}{r}520 \\
225 \\
233 \\
144 \\
124 \\
183 \\
318 \\
17\end{array}$ & $\begin{array}{r}75.0 \% \\
31.6 \% \\
33.7 \% \\
20.1 \% \\
17.7 \% \\
24.8 \% \\
45.9 \% \\
2.2 \%\end{array}$ & $\begin{array}{l}1.9 \% \\
2.0 \% \\
2.1 \% \\
1.7 \% \\
1.6 \% \\
1.8 \% \\
2.2 \% \\
0.6 \%\end{array}$ \\
\hline $\begin{array}{r}\text { Q4a. Tell us whether you favor } \\
\text { reducing, maintaining, or } \\
\text { increasing U.S. } \\
\text { production of the following } \\
\text { electricity generation types? } \\
\text { Coal } \\
(n=688)\end{array}$ & $\begin{array}{r}\text { Reduce a lot } \\
\text { Reduce somewhat } \\
\text { Maintain current levels } \\
\text { Increase somewhat } \\
\text { Increase a lot } \\
\text { Don't know }\end{array}$ & $\begin{array}{r}196 \\
151 \\
173 \\
55 \\
52 \\
61\end{array}$ & $\begin{array}{r}28.6 \% \\
22.2 \% \\
24.9 \% \\
6.8 \% \\
8.3 \% \\
9.3 \%\end{array}$ & $\begin{array}{l}2.0 \% \\
1.8 \% \\
1.9 \% \\
1.0 \% \\
1.3 \% \\
1.3 \%\end{array}$ \\
\hline $\begin{array}{r}\text { Q4b. Tell us whether you favor } \\
\text { reducing, maintaining, or } \\
\text { increasing U.S. } \\
\text { production of the following } \\
\text { electricity generation types? } \\
\text { Hydroelectric } \\
(n=693)\end{array}$ & $\begin{array}{r}\text { Reduce a lot } \\
\text { Reduce somewhat } \\
\text { Maintain current levels } \\
\text { Increase somewhat } \\
\text { Increase a lot } \\
\text { Don't know }\end{array}$ & $\begin{array}{r}25 \\
36 \\
218 \\
184 \\
173 \\
57\end{array}$ & $\begin{array}{r}3.9 \% \\
4.7 \% \\
31.7 \% \\
25.4 \% \\
26.0 \% \\
8.2 \%\end{array}$ & $\begin{array}{l}0.9 \% \\
0.9 \% \\
2.1 \% \\
1.9 \% \\
2.0 \% \\
1.2 \%\end{array}$ \\
\hline & & & & \\
\hline
\end{tabular}




\begin{tabular}{|c|c|c|c|c|}
\hline Question & Responses & $\begin{array}{c}\text { Raw } \\
\text { Frequency }\end{array}$ & $\begin{array}{l}\text { Weighted } \\
\text { Percent }\end{array}$ & $\begin{array}{l}\text { Std. } \\
\text { Error }\end{array}$ \\
\hline $\begin{array}{r}\text { Q4c. Tell us whether you } \\
\text { favor reducing, maintaining, } \\
\text { or increasing U.S. production } \\
\text { of the following electricity } \\
\text { generation types? } \\
\text { Gas ( } n=693)\end{array}$ & $\begin{array}{r}\text { Reduce a lot } \\
\text { Reduce somewhat } \\
\text { Maintain current levels } \\
\text { Increase somewhat } \\
\text { Increase a lot } \\
\text { Don't know }\end{array}$ & $\begin{array}{r}34 \\
71 \\
223 \\
155 \\
173 \\
37\end{array}$ & $\begin{array}{r}5.6 \% \\
10.6 \% \\
32.5 \% \\
21.5 \% \\
24.4 \% \\
5.4 \%\end{array}$ & $\begin{array}{l}1.1 \% \\
1.4 \% \\
2.1 \% \\
1.8 \% \\
1.9 \% \\
1.0 \%\end{array}$ \\
\hline $\begin{array}{r}\text { Q4d. Tell us whether you } \\
\text { favor reducing, maintaining, } \\
\text { or increasing U.S. production } \\
\text { of the following electricity } \\
\text { generation types? } \\
\text { Nuclear }(n=692)\end{array}$ & $\begin{array}{r}\text { Reduce a lot } \\
\text { Reduce somewhat } \\
\text { Maintain current levels } \\
\text { Increase somewhat } \\
\text { Increase a lot } \\
\text { Don't know }\end{array}$ & $\begin{array}{r}210 \\
118 \\
158 \\
98 \\
60 \\
48\end{array}$ & $\begin{array}{r}31.9 \% \\
16.6 \% \\
21.1 \% \\
15.6 \% \\
8.1 \% \\
6.7 \%\end{array}$ & $\begin{array}{l}2.1 \% \\
1.6 \% \\
1.7 \% \\
1.7 \% \\
1.2 \% \\
1.0 \%\end{array}$ \\
\hline $\begin{array}{r}\text { Q4e. Tell us whether you } \\
\text { favor reducing, maintaining, } \\
\text { or increasing U.S. production } \\
\text { of the following electricity } \\
\text { generation types? } \\
\text { Oil }(n=693)\end{array}$ & $\begin{array}{r}\text { Reduce a lot } \\
\text { Reduce somewhat } \\
\text { Maintain current levels } \\
\text { Increase somewhat } \\
\text { Increase a lot } \\
\text { Don't know } \\
\end{array}$ & $\begin{array}{r}182 \\
138 \\
147 \\
86 \\
114 \\
26 \\
\end{array}$ & $\begin{array}{r}27.1 \% \\
19.8 \% \\
21.8 \% \\
11.5 \% \\
15.4 \% \\
4.4 \% \\
\end{array}$ & $\begin{array}{l}2.0 \% \\
1.8 \% \\
1.8 \% \\
1.3 \% \\
1.5 \% \\
1.0 \%\end{array}$ \\
\hline $\begin{array}{r}\text { Q4f. Tell us whether you } \\
\text { favor reducing, maintaining, } \\
\text { or increasing U.S. production } \\
\text { of the following electricity } \\
\text { generation types? } \\
\text { Solar }(n=693)\end{array}$ & $\begin{array}{r}\text { Reduce a lot } \\
\text { Reduce somewhat } \\
\text { Maintain current levels } \\
\text { Increase somewhat } \\
\text { Increase a lot } \\
\text { Don't know }\end{array}$ & $\begin{array}{r}16 \\
22 \\
69 \\
103 \\
461 \\
22 \\
\end{array}$ & $\begin{array}{r}1.9 \% \\
3.3 \% \\
10.1 \% \\
14.8 \% \\
67.1 \% \\
2.9 \% \\
\end{array}$ & $\begin{array}{l}0.5 \% \\
0.8 \% \\
1.3 \% \\
1.6 \% \\
2.1 \% \\
0.7 \%\end{array}$ \\
\hline $\begin{array}{r}\text { Q4f. Tell us whether you } \\
\text { favor reducing, maintaining, } \\
\text { or increasing U.S. production } \\
\text { of the following electricity } \\
\text { generation types? } \\
\text { Wind ( } n=694)\end{array}$ & $\begin{array}{r}\text { Reduce a lot } \\
\text { Reduce somewhat } \\
\text { Maintain current levels } \\
\text { Increase somewhat } \\
\text { Increase a lot } \\
\text { Don't know }\end{array}$ & $\begin{array}{r}29 \\
24 \\
91 \\
138 \\
394 \\
18\end{array}$ & $\begin{array}{r}3.9 \% \\
3.4 \% \\
11.9 \% \\
19.6 \% \\
58.8 \% \\
2.3 \%\end{array}$ & $\begin{array}{l}0.8 \% \\
0.8 \% \\
1.3 \% \\
1.7 \% \\
2.1 \% \\
0.6 \%\end{array}$ \\
\hline
\end{tabular}




\begin{tabular}{|c|c|c|c|c|}
\hline Question & Responses & $\begin{array}{c}\text { Raw } \\
\text { Frequency }\end{array}$ & $\begin{array}{c}\text { Weighted } \\
\text { Percent }\end{array}$ & $\begin{array}{l}\text { Std. } \\
\text { Error }\end{array}$ \\
\hline $\begin{array}{r}\text { Q5a. How expensive do you } \\
\text { think it is to produce electricity } \\
\text { from each of the following } \\
\text { sources: } \\
\text { Coal } \\
(n=692)\end{array}$ & $\begin{array}{r}\text { Very expensive } \\
\text { Somewhat expensive } \\
\text { Moderately priced } \\
\text { Somewhat inexpensive } \\
\text { Very inexpensive } \\
\text { Don't know } \\
\end{array}$ & $\begin{array}{r}92 \\
110 \\
189 \\
142 \\
43 \\
116 \\
\end{array}$ & $\begin{array}{r}13.3 \% \\
15.0 \% \\
27.7 \% \\
23.2 \% \\
6.0 \% \\
14.9 \% \\
\end{array}$ & $\begin{array}{l}1.5 \% \\
1.5 \% \\
2.0 \% \\
2.0 \% \\
1.0 \% \\
1.5 \% \\
\end{array}$ \\
\hline $\begin{array}{r}\text { Q5b. How expensive do you } \\
\text { think it is to produce electricity } \\
\text { from each of the following } \\
\text { sources: } \\
\text { Hydroelectric } \\
(n=692)\end{array}$ & $\begin{array}{r}\text { Very expensive } \\
\text { Somewhat expensive } \\
\text { Moderately priced } \\
\text { Somewhat inexpensive } \\
\text { Very inexpensive } \\
\text { Don't know }\end{array}$ & $\begin{array}{r}85 \\
174 \\
180 \\
101 \\
38 \\
114\end{array}$ & $\begin{array}{r}13.1 \% \\
24.5 \% \\
26.5 \% \\
15.0 \% \\
5.5 \% \\
15.3 \% \\
\end{array}$ & $\begin{array}{l}1.6 \% \\
1.9 \% \\
2.0 \% \\
1.6 \% \\
1.0 \% \\
1.5 \%\end{array}$ \\
\hline $\begin{array}{r}\text { Q5c. How expensive do you } \\
\text { think it is to produce electricity } \\
\text { from each of the following } \\
\text { sources: } \\
\text { Gas } \\
(n=691)\end{array}$ & $\begin{array}{r}\text { Very expensive } \\
\text { Somewhat expensive } \\
\text { Moderately priced } \\
\text { Somewhat inexpensive } \\
\text { Very inexpensive } \\
\text { Don't know }\end{array}$ & $\begin{array}{r}56 \\
147 \\
232 \\
133 \\
54 \\
69 \\
\end{array}$ & $\begin{array}{r}7.3 \% \\
22.4 \% \\
34.8 \% \\
19.1 \% \\
7.0 \% \\
9.3 \% \\
\end{array}$ & $\begin{array}{l}1.1 \% \\
1.9 \% \\
2.1 \% \\
1.7 \% \\
1.0 \% \\
1.2 \% \\
\end{array}$ \\
\hline $\begin{array}{r}\text { Q5d. How expensive do you } \\
\text { think it is to produce electricity } \\
\text { from each of the following } \\
\text { sources: } \\
\text { Nuclear } \\
(n=688)\end{array}$ & $\begin{array}{r}\text { Very expensive } \\
\text { Somewhat expensive } \\
\text { Moderately priced } \\
\text { Somewhat inexpensive } \\
\text { Very inexpensive } \\
\text { Don't know }\end{array}$ & $\begin{array}{r}258 \\
149 \\
89 \\
49 \\
21 \\
122 \\
\end{array}$ & $\begin{array}{r}38.2 \% \\
22.8 \% \\
12.9 \% \\
7.2 \% \\
3.4 \% \\
15.5 \% \\
\end{array}$ & $\begin{array}{l}2.2 \% \\
1.9 \% \\
1.5 \% \\
1.2 \% \\
0.9 \% \\
1.5 \% \\
\end{array}$ \\
\hline $\begin{array}{r}\text { Q5e. How expensive do you } \\
\text { think it is to produce electricity } \\
\text { from each of the following } \\
\text { sources: } \\
\text { Oil } \\
(n=691)\end{array}$ & $\begin{array}{r}\text { Very expensive } \\
\text { Somewhat expensive } \\
\text { Moderately priced } \\
\text { Somewhat inexpensive } \\
\text { Very inexpensive } \\
\text { Don't know }\end{array}$ & $\begin{array}{r}266 \\
183 \\
124 \\
46 \\
15 \\
57\end{array}$ & $\begin{array}{r}39.1 \% \\
25.5 \% \\
18.3 \% \\
7.1 \% \\
2.1 \% \\
7.8 \% \\
\end{array}$ & $\begin{array}{l}2.2 \% \\
1.9 \% \\
1.7 \% \\
1.2 \% \\
0.6 \% \\
1.1 \% \\
\end{array}$ \\
\hline $\begin{array}{r}\text { Q5f. How expensive do you } \\
\text { think it is to produce electricity } \\
\text { from each of the following } \\
\text { sources: } \\
\text { Solar } \\
(n=690)\end{array}$ & $\begin{array}{r}\text { Very expensive } \\
\text { Somewhat expensive } \\
\text { Moderately priced } \\
\text { Somewhat inexpensive } \\
\text { Very inexpensive } \\
\text { Don't know } \\
\end{array}$ & $\begin{array}{r}113 \\
157 \\
146 \\
132 \\
85 \\
57 \\
\end{array}$ & $\begin{array}{r}16.6 \% \\
23.1 \% \\
20.3 \% \\
19.6 \% \\
12.1 \% \\
8.2 \% \\
\end{array}$ & $\begin{array}{l}1.7 \% \\
1.9 \% \\
1.7 \% \\
1.8 \% \\
1.4 \% \\
1.2 \% \\
\end{array}$ \\
\hline
\end{tabular}




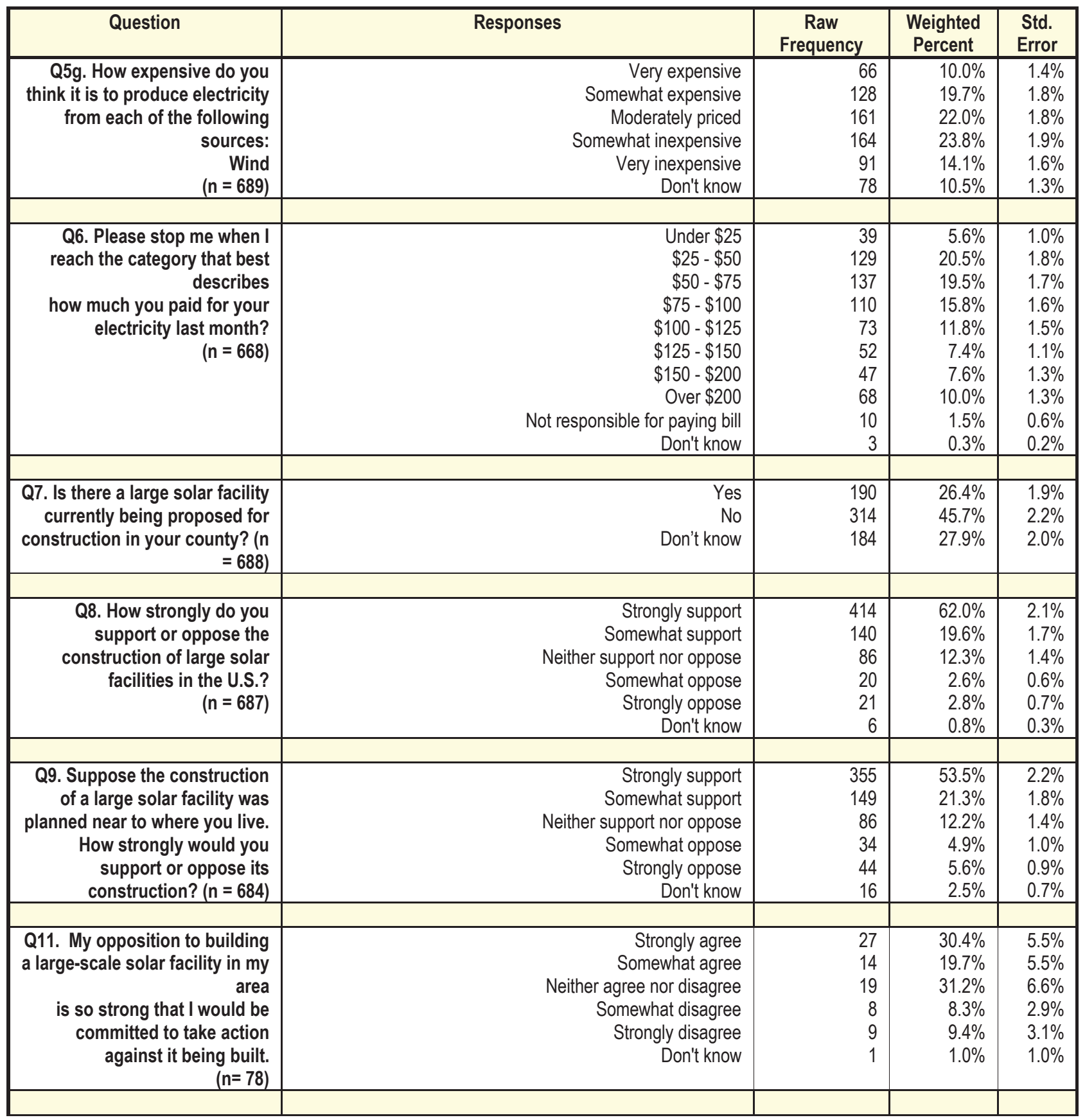




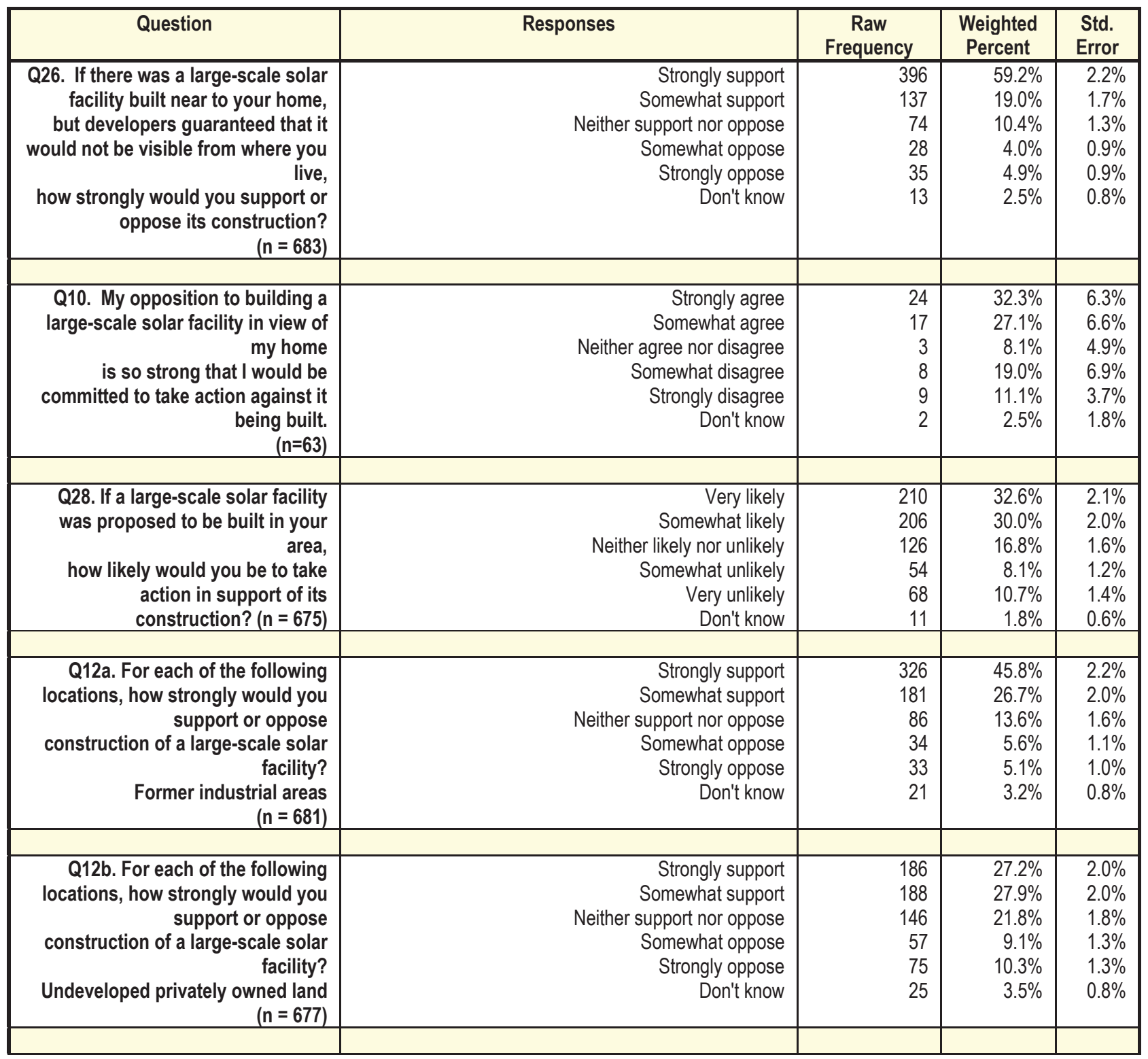




\begin{tabular}{|c|c|c|c|c|}
\hline Question & Responses & $\begin{array}{c}\text { Raw } \\
\text { Frequency }\end{array}$ & $\begin{array}{l}\text { Weighted } \\
\text { Percent }\end{array}$ & $\begin{array}{l}\text { Std. } \\
\text { Error }\end{array}$ \\
\hline $\begin{array}{r}\text { Q12c. For each of the following } \\
\text { locations, how strongly would you } \\
\text { support or oppose } \\
\text { construction of a large-scale solar } \\
\text { facility? } \\
\text { Undeveloped public land } \\
(n=676)\end{array}$ & $\begin{array}{r}\text { Strongly support } \\
\text { Somewhat support } \\
\text { Neither support nor oppose } \\
\text { Somewhat oppose } \\
\text { Strongly oppose } \\
\text { Don't know }\end{array}$ & $\begin{array}{r}218 \\
187 \\
105 \\
53 \\
78 \\
35\end{array}$ & $\begin{array}{r}31.6 \% \\
26.9 \% \\
15.1 \% \\
8.5 \% \\
12.0 \% \\
5.3 \%\end{array}$ & $\begin{array}{l}2.1 \% \\
2.0 \% \\
1.6 \% \\
1.3 \% \\
1.5 \% \\
1.0 \%\end{array}$ \\
\hline $\begin{array}{r}\text { Q12d. For each of the following } \\
\text { locations, how strongly would you } \\
\text { support or oppose } \\
\text { construction of a large-scale solar } \\
\text { facility? } \\
\text { Land currently used for agriculture } \\
(n=680)\end{array}$ & $\begin{array}{r}\text { Strongly support } \\
\text { Somewhat support } \\
\text { Neither support nor oppose } \\
\text { Somewhat oppose } \\
\text { Strongly oppose } \\
\text { Don't know }\end{array}$ & $\begin{array}{r}73 \\
95 \\
85 \\
128 \\
277 \\
22\end{array}$ & $\begin{array}{r}10.5 \% \\
14.6 \% \\
12.5 \% \\
18.9 \% \\
40.0 \% \\
3.3 \%\end{array}$ & $\begin{array}{l}1.4 \% \\
1.6 \% \\
1.5 \% \\
1.8 \% \\
2.2 \% \\
0.8 \%\end{array}$ \\
\hline $\begin{array}{r}\text { Q12e. For each of the following } \\
\text { locations, how strongly would you } \\
\text { support or oppose } \\
\text { construction of a large-scale solar } \\
\text { facility? } \\
\text { Land recently taken out of } \\
\text { agricultural production ( } n=677 \text { ) }\end{array}$ & $\begin{array}{r}\text { Strongly support } \\
\text { Somewhat support } \\
\text { Neither support nor oppose } \\
\text { Somewhat oppose } \\
\text { Strongly oppose } \\
\text { Don't know }\end{array}$ & $\begin{array}{r}181 \\
173 \\
113 \\
74 \\
109 \\
27\end{array}$ & $\begin{array}{r}25.9 \% \\
26.8 \% \\
15.6 \% \\
11.0 \% \\
16.8 \% \\
3.9 \%\end{array}$ & $\begin{array}{l}1.9 \% \\
2.0 \% \\
1.6 \% \\
1.4 \% \\
1.7 \% \\
0.8 \%\end{array}$ \\
\hline $\begin{array}{r}\text { Q12f. For each of the following } \\
\text { locations, how strongly would you } \\
\text { support or oppose } \\
\text { construction of a large-scale solar } \\
\text { facility? } \\
\text { Military bases }(n=678)\end{array}$ & $\begin{array}{r}\text { Strongly support } \\
\text { Somewhat support } \\
\text { Neither support nor oppose } \\
\text { Somewhat oppose } \\
\text { Strongly oppose } \\
\text { Don't know } \\
\end{array}$ & $\begin{array}{r}312 \\
149 \\
104 \\
38 \\
51 \\
24 \\
\end{array}$ & $\begin{array}{r}44.8 \% \\
21.7 \% \\
16.8 \% \\
5.9 \% \\
7.5 \% \\
3.3 \% \\
\end{array}$ & $\begin{array}{l}2.2 \% \\
1.8 \% \\
1.7 \% \\
1.1 \% \\
1.2 \% \\
0.7 \% \\
\end{array}$ \\
\hline $\begin{array}{r}\text { Q12g. For each of the following } \\
\text { locations, how strongly would you } \\
\text { support or oppose } \\
\text { construction of a large-scale solar } \\
\text { facility? } \\
\text { Sensitive areas for wildlife } \\
(n=680)\end{array}$ & $\begin{array}{r}\text { Strongly support } \\
\text { Somewhat support } \\
\text { Neither support nor oppose } \\
\text { Somewhat oppose } \\
\text { Strongly oppose } \\
\text { Don't know }\end{array}$ & $\begin{array}{r}54 \\
82 \\
70 \\
116 \\
335 \\
23\end{array}$ & $\begin{array}{r}7.8 \% \\
11.7 \% \\
10.6 \% \\
16.8 \% \\
49.3 \% \\
3.7 \%\end{array}$ & $\begin{array}{l}1.2 \% \\
1.4 \% \\
1.4 \% \\
1.6 \% \\
2.2 \% \\
0.9 \%\end{array}$ \\
\hline & & & & \\
\hline
\end{tabular}




\begin{tabular}{|c|c|c|c|c|}
\hline Question & Responses & $\begin{array}{c}\text { Raw } \\
\text { Frequency }\end{array}$ & $\begin{array}{l}\text { Weighted } \\
\text { Percent }\end{array}$ & $\begin{array}{l}\text { Std. } \\
\text { Error }\end{array}$ \\
\hline $\begin{array}{r}\text { 13. Of all of the following land } \\
\text { types, which one would you } \\
\text { MOST PREFER } \\
\text { to be selected for siting a large- } \\
\text { scale solar facility? } \\
(\mathrm{n}=676)\end{array}$ & $\begin{array}{r}\text { Former industrial areas } \\
\text { Undeveloped privately owned land } \\
\text { Undeveloped public land } \\
\text { Land currently used for agriculture } \\
\text { Land recently taken out of agricultural production } \\
\text { Military bases } \\
\text { Sensitive areas for wildlife } \\
\text { No preference } \\
\text { Don't know }\end{array}$ & $\begin{array}{r}230 \\
55 \\
125 \\
4 \\
53 \\
119 \\
3 \\
80 \\
7\end{array}$ & $\begin{array}{r}32.0 \% \\
10.3 \% \\
19.0 \% \\
0.4 \% \\
7.7 \% \\
16.5 \% \\
0.6 \% \\
12.6 \% \\
0.8 \%\end{array}$ & $\begin{array}{l}2.0 \% \\
1.5 \% \\
1.8 \% \\
0.2 \% \\
1.2 \% \\
1.6 \% \\
0.4 \% \\
1.5 \% \\
0.3 \%\end{array}$ \\
\hline $\begin{array}{l}\text { Q14a. What is the appropriate } \\
\text { buffer distance between a } \\
\text { large-scale solar facility and a } \\
\text { residential area? }(n=493)\end{array}$ & $\begin{array}{r}\text { Less than } 0.25 \text { miles } \\
0.25501 \text { miles } \\
1 \text { to } 5 \text { miles } \\
\text { More than } 5 \text { miles }\end{array}$ & $\begin{array}{r}60 \\
121 \\
140 \\
172\end{array}$ & $\begin{array}{l}13.2 \% \\
23.0 \% \\
27.3 \% \\
36.4 \%\end{array}$ & $\begin{array}{l}1.9 \% \\
2.1 \% \\
2.3 \% \\
2.6 \%\end{array}$ \\
\hline $\begin{array}{r}\text { Q14b. What is the appropriate } \\
\text { buffer distance between a } \\
\text { large-scale solar facility and an } \\
\text { agricultural area? }(n=469)\end{array}$ & $\begin{array}{r}\text { Less than } 0.25 \text { miles } \\
0.25501 \text { miles } \\
1 \text { to } 5 \text { miles } \\
\text { More than } 5 \text { miles }\end{array}$ & $\begin{array}{l}101 \\
100 \\
112 \\
156\end{array}$ & $\begin{array}{l}20.3 \% \\
21.1 \% \\
23.3 \% \\
35.3 \%\end{array}$ & $\begin{array}{l}2.1 \% \\
2.2 \% \\
2.3 \% \\
2.6 \%\end{array}$ \\
\hline $\begin{array}{l}\text { Q14c. What is the appropriate } \\
\text { buffer distance between a } \\
\text { large-scale solar facility and an } \\
\text { area of historical or cultural } \\
\text { importance? }(n=478)\end{array}$ & $\begin{array}{r}\text { Less than } 0.25 \text { miles } \\
0.25501 \text { miles } \\
1 \text { to } 5 \text { miles } \\
\text { More than } 5 \text { miles }\end{array}$ & $\begin{array}{r}50 \\
75 \\
150 \\
203\end{array}$ & $\begin{array}{l}10.8 \% \\
15.7 \% \\
30.0 \% \\
43.5 \%\end{array}$ & $\begin{array}{l}1.7 \% \\
1.9 \% \\
2.4 \% \\
2.7 \%\end{array}$ \\
\hline $\begin{array}{r}\text { Q14d. What is the appropriate } \\
\text { buffer distance between a } \\
\text { large-scale solar facility and a } \\
\text { wildlife migratory route? ( } \mathrm{n}= \\
485)\end{array}$ & $\begin{array}{r}\text { Less than } 0.25 \text { miles } \\
0.25501 \text { miles } \\
1 \text { to } 5 \text { miles } \\
\text { More than } 5 \text { miles }\end{array}$ & $\begin{array}{r}41 \\
70 \\
115 \\
259\end{array}$ & $\begin{array}{r}8.1 \% \\
13.6 \% \\
22.6 \% \\
55.7 \%\end{array}$ & $\begin{array}{l}1.4 \% \\
1.8 \% \\
2.2 \% \\
2.6 \%\end{array}$ \\
\hline $\begin{array}{r}\text { Q14e. What is the appropriate } \\
\text { buffer distance between a } \\
\text { large-scale solar facility and an } \\
\text { area used as a breeding } \\
\text { ground by wildlife? }(\mathrm{n}=485)\end{array}$ & $\begin{array}{r}\text { Less than } 0.25 \text { miles } \\
0.25501 \text { miles } \\
1 \text { to } 5 \text { miles } \\
\text { More than } 5 \text { miles }\end{array}$ & $\begin{array}{r}40 \\
59 \\
132 \\
254\end{array}$ & $\begin{array}{r}8.0 \% \\
11.2 \% \\
26.4 \% \\
54.4 \%\end{array}$ & $\begin{array}{l}1.4 \% \\
1.6 \% \\
2.3 \% \\
2.6 \%\end{array}$ \\
\hline $\begin{array}{l}\text { Q14f. What is the appropriate } \\
\text { buffer distance between a } \\
\text { large-scale solar facility and a } \\
\text { recreation area? }(n=489)\end{array}$ & $\begin{array}{r}\text { Less than } 0.25 \text { miles } \\
0.25501 \text { miles } \\
1 \text { to } 5 \text { miles } \\
\text { More than } 5 \text { miles }\end{array}$ & $\begin{array}{r}48 \\
61 \\
152 \\
228\end{array}$ & $\begin{array}{l}10.1 \% \\
12.7 \% \\
30.0 \% \\
47.2 \%\end{array}$ & $\begin{array}{l}1.6 \% \\
1.8 \% \\
2.4 \% \\
2.6 \%\end{array}$ \\
\hline & & & & \\
\hline
\end{tabular}




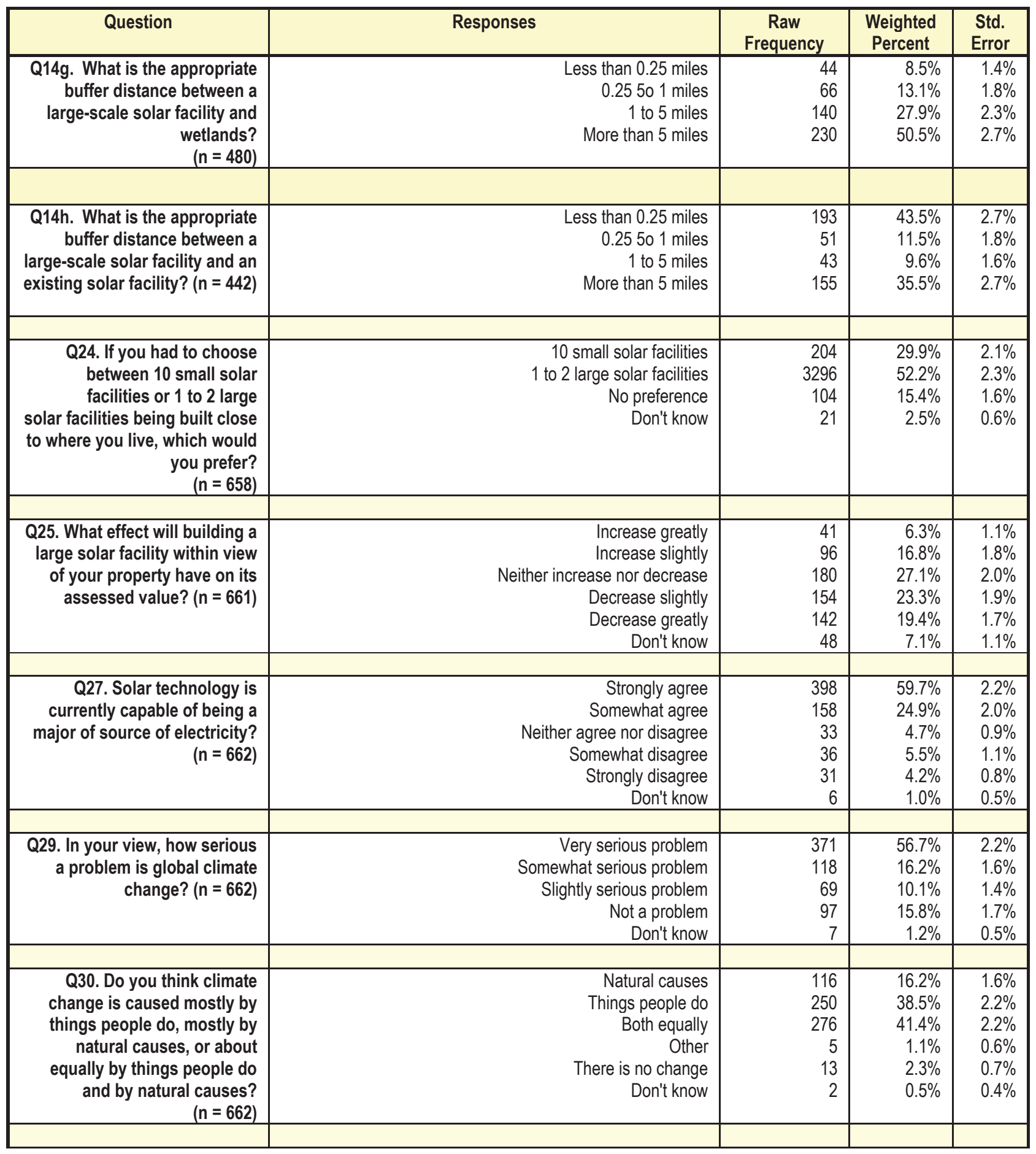




\begin{tabular}{|c|c|c|c|c|}
\hline Question & Responses & $\begin{array}{c}\text { Raw } \\
\text { Frequency }\end{array}$ & $\begin{array}{l}\text { Weighted } \\
\text { Percent }\end{array}$ & $\begin{array}{l}\text { Std. } \\
\text { Error }\end{array}$ \\
\hline $\begin{array}{r}\text { Q31. The industrialization that } \\
\text { would result from building a } \\
\text { new large-scale } \\
\text { solar facility would be good for } \\
\text { this area. } \\
(\mathrm{n}=659)\end{array}$ & $\begin{array}{r}\text { Strongly agree } \\
\text { Somewhat agree } \\
\text { Neither agree nor disagree } \\
\text { Somewhat disagree } \\
\text { Strongly disagree } \\
\text { Don't know } \\
\end{array}$ & $\begin{array}{r}285 \\
206 \\
112 \\
23 \\
19 \\
14 \\
\end{array}$ & $\begin{array}{r}44.4 \% \\
30.6 \% \\
17.5 \% \\
2.9 \% \\
2.7 \% \\
2.0 \% \\
\end{array}$ & $\begin{array}{l}2.3 \% \\
2.1 \% \\
1.8 \% \\
0.7 \% \\
0.7 \% \\
0.6 \% \\
\end{array}$ \\
\hline $\begin{array}{r}\text { Q32. The jobs that would be } \\
\text { created from building a new } \\
\text { large-scale } \\
\text { solar facility would be good for } \\
\text { this area. }(n=660)\end{array}$ & $\begin{array}{r}\text { Strongly agree } \\
\text { Somewhat agree } \\
\text { Neither agree nor disagree } \\
\text { Somewhat disagree } \\
\text { Strongly disagree } \\
\text { Don't know }\end{array}$ & $\begin{array}{r}447 \\
140 \\
31 \\
19 \\
17 \\
6\end{array}$ & $\begin{array}{r}66.3 \% \\
22.9 \% \\
4.3 \% \\
3.2 \% \\
2.2 \% \\
1.1 \%\end{array}$ & $\begin{array}{l}2.2 \% \\
2.0 \% \\
0.9 \% \\
0.9 \% \\
0.5 \% \\
0.5 \%\end{array}$ \\
\hline $\begin{array}{r}\text { Q33. Building a large-scale } \\
\text { solar facility nearby will bring } \\
\text { too much construction traffic to } \\
\text { the area. }(n=659)\end{array}$ & $\begin{array}{r}\text { Strongly agree } \\
\text { Somewhat agree } \\
\text { Neither agree nor disagree } \\
\text { Somewhat disagree } \\
\text { Strongly disagree } \\
\text { Don't know }\end{array}$ & $\begin{array}{r}69 \\
129 \\
107 \\
177 \\
157 \\
20\end{array}$ & $\begin{array}{r}9.5 \% \\
20.6 \% \\
16.7 \% \\
26.2 \% \\
23.9 \% \\
3.1 \% \\
\end{array}$ & $\begin{array}{l}1.2 \% \\
1.9 \% \\
1.7 \% \\
2.0 \% \\
1.9 \% \\
0.8 \%\end{array}$ \\
\hline $\begin{array}{r}\text { Q34. Citizens do not have } \\
\text { enough opportunity to } \\
\text { participate in planning how } \\
\text { and where a new large-scale } \\
\text { solar facility will be built. } \\
(\mathrm{n}=659)\end{array}$ & $\begin{array}{r}\text { Strongly agree } \\
\text { Somewhat agree } \\
\text { Neither agree nor disagree } \\
\text { Somewhat disagree } \\
\text { Strongly disagree } \\
\text { Don't know }\end{array}$ & $\begin{array}{r}173 \\
196 \\
101 \\
92 \\
58 \\
39\end{array}$ & $\begin{array}{r}25.2 \% \\
31.3 \% \\
15.0 \% \\
13.8 \% \\
9.0 \% \\
5.7 \% \\
\end{array}$ & $\begin{array}{l}1.9 \% \\
2.1 \% \\
1.6 \% \\
1.6 \% \\
1.3 \% \\
1.0 \%\end{array}$ \\
\hline $\begin{array}{r}\text { Q35. A large-scale solar facility } \\
\text { that meets all current state and } \\
\text { local laws } \\
\text { should be allowed even if } \\
\text { people living near it are } \\
\text { opposed to it. }(n=657)\end{array}$ & $\begin{array}{r}\text { Strongly agree } \\
\text { Somewhat agree } \\
\text { Neither agree nor disagree } \\
\text { Somewhat disagree } \\
\text { Strongly disagree } \\
\text { Don't know }\end{array}$ & $\begin{array}{r}149 \\
168 \\
100 \\
99 \\
123 \\
18\end{array}$ & $\begin{array}{r}22.6 \% \\
27.3 \% \\
15.4 \% \\
13.9 \% \\
17.6 \% \\
3.1 \% \\
\end{array}$ & $\begin{array}{l}1.9 \% \\
2.1 \% \\
1.7 \% \\
1.5 \% \\
1.7 \% \\
0.8 \%\end{array}$ \\
\hline $\begin{array}{r}\text { Q36. I don't want the landscape } \\
\text { of this place to change. }(n= \\
652)\end{array}$ & $\begin{array}{r}\text { Strongly agree } \\
\text { Somewhat agree } \\
\text { Neither agree nor disagree } \\
\text { Somewhat disagree } \\
\text { Strongly disagree } \\
\text { Don't know }\end{array}$ & $\begin{array}{r}191 \\
147 \\
183 \\
82 \\
47 \\
3 \\
\end{array}$ & $\begin{array}{r}27.9 \% \\
23.0 \% \\
30.3 \% \\
11.6 \% \\
6.6 \% \\
0.6 \% \\
\end{array}$ & $\begin{array}{l}2.0 \% \\
1.9 \% \\
2.2 \% \\
1.4 \% \\
1.1 \% \\
0.4 \%\end{array}$ \\
\hline
\end{tabular}




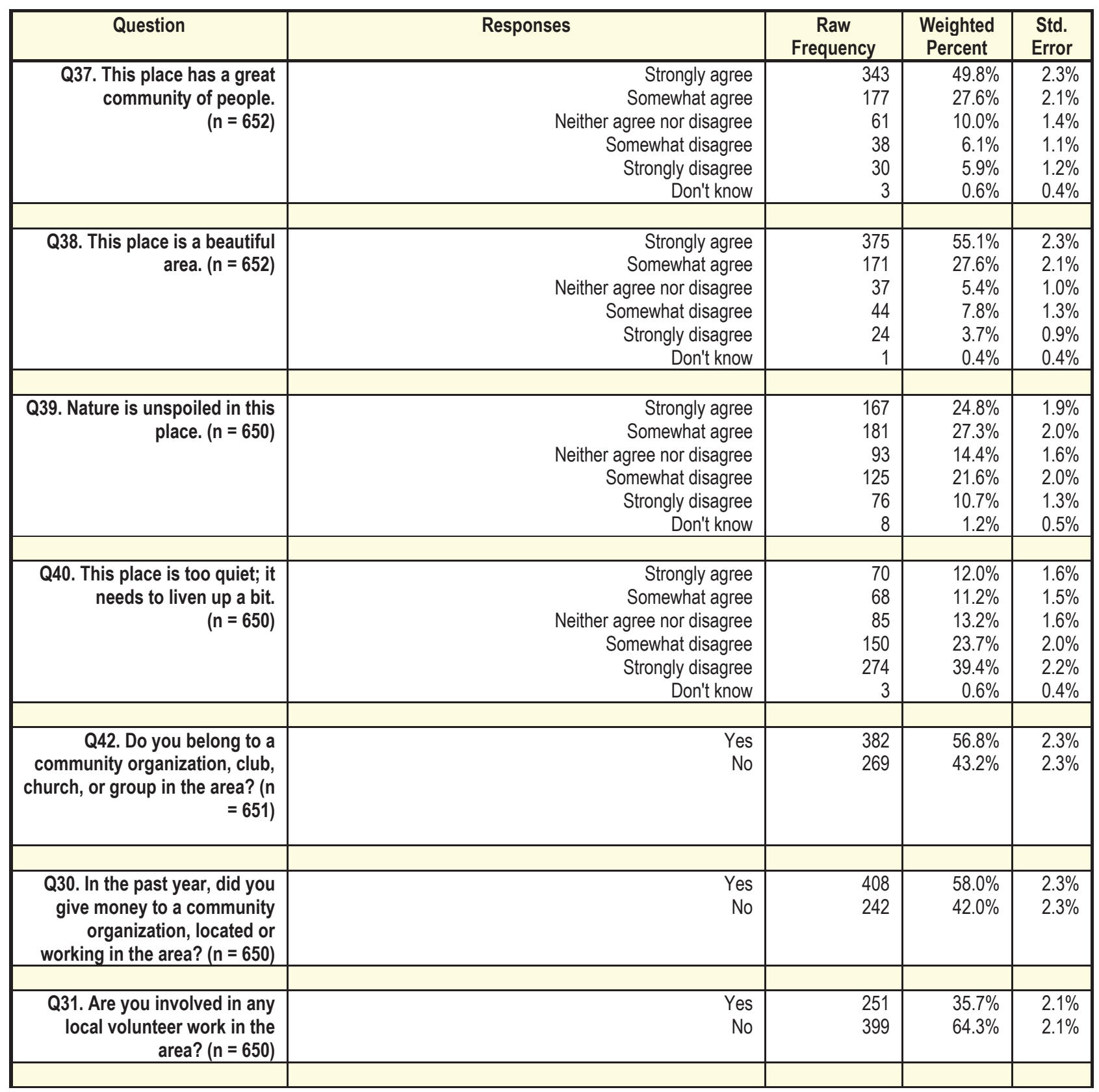




\begin{tabular}{|c|c|c|c|c|}
\hline Question & Responses & $\begin{array}{c}\text { Raw } \\
\text { Frequency }\end{array}$ & $\begin{array}{l}\text { Weighed } \\
\text { Percent }\end{array}$ & $\begin{array}{l}\text { Std. } \\
\text { Error }\end{array}$ \\
\hline $\begin{array}{l}\text { Q63. What effect will building } \\
\text { more large-scale solar facilities } \\
\text { have on wildlife? }(n=633)\end{array}$ & $\begin{array}{r}\text { Very positive effect } \\
\text { Somewhat positive effect } \\
\text { No effect } \\
\text { Somewhat negative effect } \\
\text { Very negative effect } \\
\text { Don't know }\end{array}$ & $\begin{array}{r}31 \\
80 \\
166 \\
216 \\
53 \\
87\end{array}$ & $\begin{array}{r}4.9 \% \\
14.1 \% \\
25.5 \% \\
35.0 \% \\
7.3 \% \\
12.2 \%\end{array}$ & $\begin{array}{l}1.0 \% \\
1.7 \% \\
2.0 \% \\
2.2 \% \\
1.1 \% \\
1.4 \%\end{array}$ \\
\hline $\begin{array}{r}\text { Q64. Have you previously taken } \\
\text { action against the building of a } \\
\text { solar facility } \\
\text { in your county (attended public } \\
\text { meetings, written letters, } \\
\text { protested, etc.)? } \\
(\mathrm{n}=632)\end{array}$ & $\begin{array}{r}\text { Yes } \\
\text { No } \\
\text { Don't know }\end{array}$ & $\begin{array}{r}9 \\
622 \\
1\end{array}$ & $\begin{array}{r}98.3 \% \\
1.6 \% \\
0.1 \%\end{array}$ & $\begin{array}{l}0.6 \% \\
0.6 \% \\
0.1 \%\end{array}$ \\
\hline $\begin{array}{r}\text { Q65. How important or } \\
\text { unimportant is protecting the } \\
\text { environment to you } \\
\text { personally? }(n=484)\end{array}$ & $\begin{array}{r}\text { Very important } \\
\text { Important } \\
\text { Unimportant } \\
\text { Very unimportant } \\
\text { Don't know }\end{array}$ & $\begin{array}{r}352 \\
114 \\
11 \\
4 \\
3\end{array}$ & $\begin{array}{r}73.3 \% \\
21.8 \% \\
3.0 \% \\
1.0 \% \\
0.9 \%\end{array}$ & $\begin{array}{l}2.3 \% \\
2.1 \% \\
1.0 \% \\
0.6 \% \\
0.6 \%\end{array}$ \\
\hline $\begin{array}{r}\text { Q67. Do you have solar panels } \\
\text { installed on the rooftop of your } \\
\text { residence? }(n=476)\end{array}$ & $\begin{array}{r}\text { No } \\
\text { Yes } \\
\text { Don't know }\end{array}$ & $\begin{array}{r}384 \\
31 \\
61\end{array}$ & $\begin{array}{r}79.7 \% \\
6.4 \% \\
13.9 \%\end{array}$ & $\begin{array}{l}2.2 \% \\
1.3 \% \\
1.9 \%\end{array}$ \\
\hline $\begin{array}{r}\text { Q45. Do you consider yourself } \\
\text { to live in rural, urban, or } \\
\text { suburban area? } \\
(n=643)\end{array}$ & $\begin{array}{r}\text { Rural } \\
\text { Urban } \\
\text { Suburban } \\
\text { Refused }\end{array}$ & $\begin{array}{r}197 \\
114 \\
325 \\
7\end{array}$ & $\begin{array}{r}30.7 \% \\
19.4 \% \\
48.4 \% \\
1.4 \%\end{array}$ & $\begin{array}{l}2.1 \% \\
1.9 \% \\
2.3 \% \\
0.6 \%\end{array}$ \\
\hline
\end{tabular}




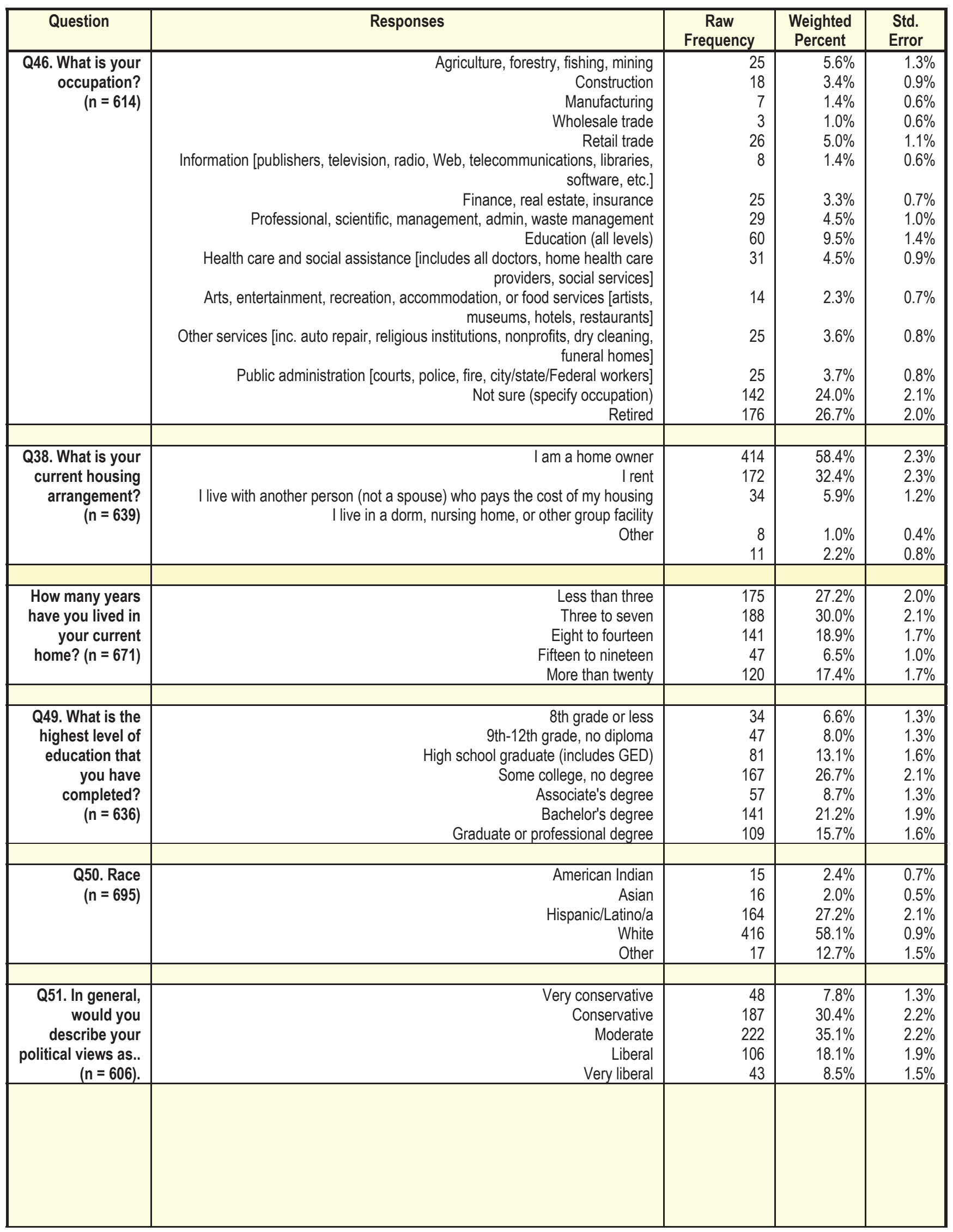




\begin{tabular}{|c|c|c|c|c|}
\hline Question & Responses & $\begin{array}{c}\text { Raw } \\
\text { Frequency }\end{array}$ & $\begin{array}{c}\text { Weighted } \\
\text { Percent }\end{array}$ & $\begin{array}{l}\text { Std. } \\
\text { Error }\end{array}$ \\
\hline $\begin{array}{r}\text { Q52. In politics today, do you } \\
\text { consider yourself a } \\
\text { Republican, Democrat, or } \\
\text { Independent? }(\mathrm{n}=620)\end{array}$ & $\begin{array}{r}\text { Republican } \\
\text { Democrat } \\
\text { Independent/no preference/other } \\
\text { Don't know }\end{array}$ & $\begin{array}{r}170 \\
202 \\
236 \\
12\end{array}$ & $\begin{array}{r}25.1 \% \\
34.8 \% \\
36.0 \% \\
2.0 \%\end{array}$ & $\begin{array}{l}1.9 \% \\
2.3 \% \\
2.3 \% \\
0.7 \%\end{array}$ \\
\hline $\begin{array}{r}\text { Income } \\
(n=582)\end{array}$ & $\begin{array}{r}\text { Less than } \$ 24,999 \\
\text { Between } \$ 25,000 \text { and } \$ 49,999 \\
\text { Between } \$ 50,000 \text { and } \$ 74,999 \\
\text { Between } \$ 75,000 \text { and } \$ 99,999 \\
\text { More than } \$ 100,000 \\
\end{array}$ & $\begin{array}{r}109 \\
152 \\
103 \\
76 \\
142 \\
\end{array}$ & $\begin{array}{l}21.6 \% \\
26.4 \% \\
16.0 \% \\
12.8 \% \\
23.2 \% \\
\end{array}$ & $\begin{array}{l}2.1 \% \\
2.1 \% \\
1.7 \% \\
1.6 \% \\
2.0 \% \\
\end{array}$ \\
\hline $\begin{array}{r}\text { How many years have you lived } \\
\text { in this area? }(n=657)\end{array}$ & $\begin{array}{r}\text { Less than five } \\
\text { Five to nine } \\
\text { Ten to fourteen } \\
\text { Fifteen to nineteen } \\
\text { More than twenty }\end{array}$ & $\begin{array}{r}135 \\
109 \\
93 \\
59 \\
261\end{array}$ & $\begin{array}{r}19.3 \% \\
16.4 \% \\
15.7 \% \\
8.9 \% \\
39.8 \% \\
\end{array}$ & $\begin{array}{l}1.7 \% \\
1.7 \% \\
1.7 \% \\
1.3 \% \\
2.2 \%\end{array}$ \\
\hline $\begin{array}{r}\text { County } \\
(n=641)\end{array}$ & $\begin{array}{r}\text { Inyo } \\
\text { Kern } \\
\text { Riverside } \\
\text { San Bernardino } \\
\text { San Luis Obispo } \\
\text { Ventura } \\
\end{array}$ & $\begin{array}{r}4 \\
99 \\
211 \\
204 \\
39 \\
84\end{array}$ & $\begin{array}{r}0.5 \% \\
16.9 \% \\
32.1 \% \\
31.6 \% \\
6.2 \% \\
12.8 \% \\
\end{array}$ & $\begin{array}{l}0.2 \% \\
1.8 \% \\
2.1 \% \\
2.1 \% \\
1.1 \% \\
1.5 \% \\
\end{array}$ \\
\hline Gender $(n=641)$ & $\begin{array}{r}\text { Male } \\
\text { Female }\end{array}$ & $\begin{array}{l}287 \\
354\end{array}$ & $\begin{array}{l}48.7 \% \\
51.3 \%\end{array}$ & $\begin{array}{l}2.3 \% \\
2.3 \%\end{array}$ \\
\hline Language & $\begin{array}{l}\text { English } \\
\text { Spanish }\end{array}$ & $\begin{array}{r}613 \\
82 \\
\end{array}$ & $\begin{array}{l}86.8 \% \\
13.2 \% \\
\end{array}$ & $\begin{array}{l}1.5 \% \\
1.5 \% \\
\end{array}$ \\
\hline Q55. Age & $\begin{array}{r}18-34 \\
35-44 \\
45-54 \\
55-64 \\
65 \text { and older }\end{array}$ & $\begin{array}{l}83.7 \\
58.4 \\
61.7 \\
70.1 \\
99.9\end{array}$ & $\begin{array}{l}22.4 \% \\
15.6 \% \\
16.5 \% \\
18.8 \% \\
26.7 \%\end{array}$ & $\begin{array}{l}3.1 \% \\
2.4 \% \\
2.3 \% \\
2.2 \% \\
2.6 \%\end{array}$ \\
\hline
\end{tabular}


Descriptive Statistics for Quantitative Questions

\begin{tabular}{|c|c|c|c|}
\hline Question & Mean (miles) & Std. Error (miles) & $\begin{array}{c}\text { Std. } \\
\text { Deviation } \\
\text { (miles) }\end{array}$ \\
\hline $\begin{array}{r}\text { Q14: Appropriate buffer distance between a utility scale solar facility } \\
\text { and a residential area }\end{array}$ & 21.72 & 7.82 & $3,917.68$ \\
\hline $\begin{array}{r}\text { Q15: Appropriate buffer distance between a utility scale solar facility } \\
\text { and a agricultural area }\end{array}$ & 19.85 & 8.02 & $3,852.04$ \\
\hline $\begin{array}{r}\text { Q16: Appropriate buffer distance between a utility scale solar facility } \\
\text { and an area of historic or cultural importance }\end{array}$ & 27.58 & 8.31 & $4,059.47$ \\
\hline $\begin{array}{r}\text { Q17: Appropriate buffer distance between a utility scale solar facility } \\
\text { and a wildlife migratory route }\end{array}$ & 34.16 & 8.59 & $4,227.56$ \\
\hline $\begin{array}{r}\text { Q18: Appropriate buffer distance between a utility scale solar facility } \\
\text { and a breeding ground used by wildlife }\end{array}$ & 37.15 & 8.80 & $4,322.16$ \\
\hline $\begin{array}{r}\text { Q19: Appropriate buffer distance between a utility scale solar facility } \\
\text { and an used for recreation }\end{array}$ & 33.82 & 9.60 & $4,780.42$ \\
\hline $\begin{array}{r}\text { Q20: Appropriate buffer distance between a utility scale solar facility } \\
\text { and a wetland }\end{array}$ & 35.38 & 9.74 & $4,777.67$ \\
\hline $\begin{array}{r}\text { Q21: Appropriate buffer distance between a utility scale solar facility } \\
\text { and an existing solar facility }\end{array}$ & 31.77 & 8.86 & $4,404.98$ \\
\hline
\end{tabular}


Appendix B: National Frequencies

\begin{tabular}{|c|c|c|c|c|}
\hline Question & Responses & $\begin{array}{c}\text { Raw } \\
\text { Frequency }\end{array}$ & $\begin{array}{l}\text { Weighted } \\
\text { Percent }\end{array}$ & $\begin{array}{l}\text { Std. } \\
\text { Error }\end{array}$ \\
\hline $\begin{array}{r}\text { Q1. Which of the following } \\
\text { statements best describes how } \\
\text { closely you follow energy } \\
\text { issues? } \\
(n=429)\end{array}$ & $\begin{array}{l}\text { You follow energy issues very closely } \\
\text { You sometimes pay attention to energy issues } \\
\text { You rarely pay attention to energy issues } \\
\text { You never pay attention to energy issues } \\
\text { Don't know }\end{array}$ & $\begin{array}{r}176 \\
209 \\
30 \\
14 \\
0\end{array}$ & $\begin{array}{r}39.8 \% \\
48.6 \% \\
7.5 \% \\
4.1 \% \\
0.0 \%\end{array}$ & $\begin{array}{l}2.8 \% \\
2.9 \% \\
1.6 \% \\
1.3 \% \\
0.0 \%\end{array}$ \\
\hline $\begin{array}{l}\text { Q2. Where do you get most of } \\
\text { your information about energy? } \\
\qquad(\mathrm{n}=428)\end{array}$ & $\begin{array}{r}\text { Newspaper (print or online) } \\
\text { Local Newspaper } \\
\text { Magazine(s) } \\
\text { Books } \\
\text { Friends } \\
\text { The Internet } \\
\text { An organization or interest group } \\
\text { TV news (please specify) } \\
\text { TV documentaries } \\
\text { Other source (please specify) } \\
\text { Don't know }\end{array}$ & $\begin{array}{r}36 \\
46 \\
15 \\
3 \\
11 \\
125 \\
12 \\
112 \\
22 \\
43 \\
3\end{array}$ & $\begin{array}{r}7.7 \% \\
10.5 \% \\
3.4 \% \\
0.5 \% \\
3.0 \% \\
30.6 \% \\
2.8 \% \\
25.2 \% \\
4.9 \% \\
10.9 \% \\
0.7 \%\end{array}$ & $\begin{array}{l}1.5 \% \\
1.8 \% \\
1.0 \% \\
0.3 \% \\
1.1 \% \\
2.8 \% \\
0.9 \% \\
2.5 \% \\
1.2 \% \\
1.9 \% \\
0.5 \%\end{array}$ \\
\hline $\begin{array}{r}\text { Q3. In considering energy } \\
\text { sources, which of the following } \\
\text { factors are most important to } \\
\text { you? } \\
(n=430)\end{array}$ & $\begin{array}{r}\text { Cost } \\
\text { Reliability } \\
\text { Safety } \\
\text { Whether or not it is produced domestically/locally } \\
\text { Job opportunities } \\
\text { Whether or not it is renewable } \\
\text { Environmental impacts } \\
\text { Other }\end{array}$ & $\begin{array}{r}317 \\
119 \\
143 \\
113 \\
71 \\
129 \\
214 \\
15\end{array}$ & $\begin{array}{r}75.2 \% \\
26.6 \% \\
30.6 \% \\
25.1 \% \\
15.9 \% \\
31.1 \% \\
52.3 \% \\
3.6 \%\end{array}$ & $\begin{array}{l}2.5 \% \\
2.5 \% \\
2.6 \% \\
2.5 \% \\
2.1 \% \\
2.7 \% \\
2.9 \% \\
1.1 \%\end{array}$ \\
\hline $\begin{array}{r}\text { Q4a. Tell us whether you favor } \\
\text { reducing, maintaining, or } \\
\text { increasing U.S. } \\
\text { production of the following } \\
\text { electricity generation types? } \\
\text { Coal } \\
(n=424)\end{array}$ & $\begin{array}{r}\text { Cease } \\
\text { Reduce } \\
\text { Maintain current levels } \\
\text { Increase } \\
\text { Don't know }\end{array}$ & $\begin{array}{r}33 \\
138 \\
145 \\
88 \\
20\end{array}$ & $\begin{array}{r}9.1 \% \\
34.7 \% \\
30.5 \% \\
20.5 \% \\
5.3 \%\end{array}$ & $\begin{array}{l}1.8 \% \\
2.8 \% \\
2.6 \% \\
2.4 \% \\
1.4 \%\end{array}$ \\
\hline $\begin{array}{r}\text { Q4b. Tell us whether you favor } \\
\text { reducing, maintaining, or } \\
\text { increasing U.S. } \\
\text { production of the following } \\
\text { electricity generation types? } \\
\text { Hydroelectric } \\
(n=425)\end{array}$ & $\begin{array}{r}\text { Cease } \\
\text { Reduce } \\
\text { Maintain current levels } \\
\text { Increase } \\
\text { Don't know }\end{array}$ & $\begin{array}{r}3 \\
22 \\
144 \\
226 \\
30\end{array}$ & $\begin{array}{r}0.5 \% \\
4.1 \% \\
34.8 \% \\
53.2 \% \\
7.5 \%\end{array}$ & $\begin{array}{l}0.3 \% \\
1.0 \% \\
2.8 \% \\
2.9 \% \\
1.6 \%\end{array}$ \\
\hline
\end{tabular}




\begin{tabular}{|c|c|c|c|c|}
\hline Question & Responses & $\begin{array}{c}\text { Raw } \\
\text { Frequency }\end{array}$ & $\begin{array}{l}\text { Weighted } \\
\text { Percent }\end{array}$ & $\begin{array}{l}\text { Std. } \\
\text { Error }\end{array}$ \\
\hline $\begin{array}{r}\text { Q4c. Tell us whether you } \\
\text { favor reducing, maintaining, } \\
\text { or increasing U.S. production } \\
\text { of the following electricity } \\
\text { generation types? } \\
\text { Gas ( } n=424)\end{array}$ & $\begin{array}{r}\text { Cease } \\
\text { Reduce } \\
\text { Maintain current levels } \\
\text { Increase } \\
\text { Don't know }\end{array}$ & $\begin{array}{r}6 \\
71 \\
138 \\
196 \\
13\end{array}$ & $\begin{array}{r}1.6 \% \\
19.5 \% \\
33.3 \% \\
41.9 \% \\
3.7 \%\end{array}$ & $\begin{array}{l}0.8 \% \\
2.5 \% \\
2.8 \% \\
2.9 \% \\
1.2 \%\end{array}$ \\
\hline $\begin{array}{r}\text { Q4d. Tell us whether you } \\
\text { favor reducing, maintaining, } \\
\text { or increasing U.S. production } \\
\text { of the following electricity } \\
\text { generation types? } \\
\text { Nuclear ( } n=422)\end{array}$ & $\begin{array}{r}\text { Cease } \\
\text { Reduce } \\
\text { Maintain current levels } \\
\text { Increase } \\
\text { Don't know }\end{array}$ & $\begin{array}{r}69 \\
100 \\
128 \\
99 \\
26\end{array}$ & $\begin{array}{r}15.9 \% \\
24.0 \% \\
30.1 \% \\
23.6 \% \\
6.5 \%\end{array}$ & $\begin{array}{l}2.1 \% \\
2.5 \% \\
2.7 \% \\
2.5 \% \\
1.5 \%\end{array}$ \\
\hline $\begin{array}{r}\text { Q4e. Tell us whether you } \\
\text { favor reducing, maintaining, } \\
\text { or increasing U.S. production } \\
\text { of the following electricity } \\
\text { generation types? } \\
\text { Oil ( } n=422)\end{array}$ & $\begin{array}{r}\text { Cease } \\
\text { Reduce } \\
\text { Maintain current levels } \\
\text { Increase } \\
\text { Don't know }\end{array}$ & $\begin{array}{r}26 \\
129 \\
130 \\
130 \\
7\end{array}$ & $\begin{array}{r}6.7 \% \\
33.1 \% \\
28.9 \% \\
29.1 \% \\
2.2 \%\end{array}$ & $\begin{array}{l}1.5 \% \\
2.8 \% \\
2.6 \% \\
2.6 \% \\
1.0 \%\end{array}$ \\
\hline $\begin{array}{r}\text { Q4f. Tell us whether you } \\
\text { favor reducing, maintaining, } \\
\text { or increasing U.S. production } \\
\text { of the following electricity } \\
\text { generation types? } \\
\text { Solar }(n=423)\end{array}$ & $\begin{array}{r}\text { Cease } \\
\text { Reduce } \\
\text { Maintain current levels } \\
\text { Increase } \\
\text { Don't know }\end{array}$ & $\begin{array}{r}6 \\
18 \\
49 \\
342 \\
8\end{array}$ & $\begin{array}{r}1.2 \% \\
3.5 \% \\
13.4 \% \\
80.2 \% \\
1.7 \%\end{array}$ & $\begin{array}{l}0.5 \% \\
0.9 \% \\
2.1 \% \\
2.4 \% \\
0.7 \%\end{array}$ \\
\hline $\begin{array}{r}\text { Q4g. Tell us whether you } \\
\text { favor reducing, maintaining, } \\
\text { or increasing U.S. production } \\
\text { of the following electricity } \\
\text { generation types? } \\
\text { Wind ( } n=423 \text { ) }\end{array}$ & $\begin{array}{r}\text { Cease } \\
\text { Reduce } \\
\text { Maintain current levels } \\
\text { Increase } \\
\text { Don't know }\end{array}$ & $\begin{array}{r}12 \\
22 \\
62 \\
319 \\
8\end{array}$ & $\begin{array}{r}2.5 \% \\
4.3 \% \\
15.3 \% \\
76.1 \% \\
1.9 \%\end{array}$ & $\begin{array}{l}0.9 \% \\
1.1 \% \\
2.1 \% \\
2.5 \% \\
0.8 \%\end{array}$ \\
\hline & & & & \\
\hline
\end{tabular}




\begin{tabular}{|c|c|c|c|c|}
\hline Question & Responses & $\begin{array}{c}\text { Raw } \\
\text { Frequency }\end{array}$ & $\begin{array}{l}\text { Weighted } \\
\text { Percent }\end{array}$ & $\begin{array}{l}\text { Std. } \\
\text { Error }\end{array}$ \\
\hline $\begin{array}{r}\text { Q6. How strongly do you } \\
\text { support or oppose the } \\
\text { construction of large solar } \\
\text { facilities in the U.S.? } \\
(n=423)\end{array}$ & $\begin{array}{r}\text { Strongly support } \\
\text { Somewhat support } \\
\text { Neither support nor oppose } \\
\text { Somewhat oppose } \\
\text { Strongly oppose } \\
\text { Don't know }\end{array}$ & $\begin{array}{r}213 \\
112 \\
50 \\
15 \\
24 \\
9 \\
\end{array}$ & $\begin{array}{r}51.3 \% \\
26.1 \% \\
11.7 \% \\
4.0 \% \\
5.1 \% \\
1.8 \% \\
\end{array}$ & $\begin{array}{l}2.9 \% \\
2.6 \% \\
1.9 \% \\
1.2 \% \\
1.2 \% \\
0.7 \% \\
\end{array}$ \\
\hline $\begin{array}{r}\text { Q7. Solar technology is } \\
\text { currently capable of being a } \\
\text { major of source of electricity? } \\
(n=423)\end{array}$ & $\begin{array}{r}\text { Strongly agree } \\
\text { Somewhat agree } \\
\text { Neither agree nor disagree } \\
\text { Somewhat disagree } \\
\text { Strongly disagree } \\
\text { Don't know }\end{array}$ & $\begin{array}{r}163 \\
141 \\
38 \\
34 \\
39 \\
8\end{array}$ & $\begin{array}{r}39.9 \% \\
32.7 \% \\
8.3 \% \\
7.9 \% \\
9.7 \% \\
1.5 \% \\
\end{array}$ & $\begin{array}{l}2.9 \% \\
2.7 \% \\
1.5 \% \\
1.6 \% \\
1.8 \% \\
0.6 \%\end{array}$ \\
\hline $\begin{array}{l}\text { Q8. What is an acceptable } \\
\text { buffer distance between a large } \\
\text { solar facility and existing } \\
\text { agricultural land? ( }=413 \text { ) }\end{array}$ & $\begin{array}{r}\text { Less than a mile } \\
1-5 \text { miles } \\
6-10 \text { miles } \\
\text { More than } 10 \text { miles } \\
\text { No preference } \\
\text { Don't know }\end{array}$ & $\begin{array}{r}107 \\
90 \\
44 \\
52 \\
41 \\
79\end{array}$ & $\begin{array}{r}26.3 \% \\
22.5 \% \\
11.6 \% \\
13.3 \% \\
8.4 \% \\
17.8 \% \\
\end{array}$ & $\begin{array}{l}2.6 \% \\
2.5 \% \\
2.0 \% \\
2.1 \% \\
1.5 \% \\
2.2 \%\end{array}$ \\
\hline $\begin{array}{r}\text { Q9. What is an acceptable } \\
\text { buffer distance between a large } \\
\text { solar facility and your home? } \\
(\mathrm{n}=417)\end{array}$ & $\begin{array}{r}\text { Less than a mile } \\
1-5 \text { miles } \\
6-10 \text { miles } \\
\text { More than } 10 \text { miles } \\
\text { No Preference } \\
\text { Don't know }\end{array}$ & $\begin{array}{r}85 \\
110 \\
63 \\
88 \\
29 \\
42\end{array}$ & $\begin{array}{r}21.4 \% \\
25.5 \% \\
15.9 \% \\
20.9 \% \\
5.6 \% \\
10.7 \% \\
\end{array}$ & $\begin{array}{l}2.5 \% \\
2.6 \% \\
2.2 \% \\
2.4 \% \\
1.2 \% \\
1.9 \% \\
\end{array}$ \\
\hline $\begin{array}{l}\text { Q10. How concerned are you } \\
\text { about global climate change? } \\
\qquad(\mathrm{n}=421)\end{array}$ & $\begin{array}{r}\text { Greatly concerned } \\
\text { Somewhat concerned } \\
\text { Slightly concerned } \\
\text { Not concerned } \\
\text { Don't know } \\
\end{array}$ & $\begin{array}{r}171 \\
119 \\
46 \\
82 \\
3 \\
\end{array}$ & $\begin{array}{r}43.3 \% \\
26.0 \% \\
11.1 \% \\
18.2 \% \\
1.3 \% \\
\end{array}$ & $\begin{array}{l}2.9 \% \\
2.5 \% \\
1.9 \% \\
2.2 \% \\
0.8 \% \\
\end{array}$ \\
\hline $\begin{array}{r}\text { Q11. Do you think climate } \\
\text { change is caused mostly by } \\
\text { things people do, mostly by } \\
\text { natural causes, or about } \\
\text { equally by things people do } \\
\text { and by natural causes? } \\
(n=420)\end{array}$ & $\begin{array}{r}\text { Natural causes } \\
\text { Things people do } \\
\text { Both equally } \\
\text { Other } \\
\text { There is no change } \\
\text { Don't know }\end{array}$ & $\begin{array}{r}77 \\
142 \\
163 \\
9 \\
16 \\
13\end{array}$ & $\begin{array}{r}16.4 \% \\
36.7 \% \\
38.0 \% \\
1.8 \% \\
3.8 \% \\
3.4 \%\end{array}$ & $\begin{array}{l}2.1 \% \\
2.9 \% \\
2.9 \% \\
0.7 \% \\
1.1 \% \\
1.1 \%\end{array}$ \\
\hline & & & & \\
\hline
\end{tabular}




\begin{tabular}{|c|c|c|c|c|}
\hline Question & Responses & $\begin{array}{c}\text { Raw } \\
\text { Frequency }\end{array}$ & $\begin{array}{c}\text { Weighted } \\
\text { Percent }\end{array}$ & $\begin{array}{l}\text { Std. } \\
\text { Error }\end{array}$ \\
\hline $\begin{array}{l}\text { Q12. I don't want the landscape } \\
\text { of this place to change. }(n= \\
416)\end{array}$ & $\begin{array}{r}\text { Strongly agree } \\
\text { Somewhat agree } \\
\text { Neither agree nor disagree } \\
\text { Somewhat disagree } \\
\text { Strongly disagree } \\
\text { Don't know } \\
\end{array}$ & $\begin{array}{r}151 \\
106 \\
80 \\
48 \\
22 \\
9 \\
\end{array}$ & $\begin{array}{r}34.3 \% \\
25.1 \% \\
19.5 \% \\
12.8 \% \\
5.7 \% \\
2.7 \% \\
\end{array}$ & $\begin{array}{l}2.8 \% \\
2.5 \% \\
2.4 \% \\
2.1 \% \\
1.4 \% \\
1.1 \% \\
\end{array}$ \\
\hline $\begin{array}{l}\text { Q13. This place has a great } \\
\text { community of people. } \\
(n=418)\end{array}$ & $\begin{array}{r}\text { Strongly agree } \\
\text { Somewhat agree } \\
\text { Neither agree nor disagree } \\
\text { Somewhat disagree } \\
\text { Strongly disagree } \\
\text { Don't know }\end{array}$ & $\begin{array}{r}244 \\
108 \\
27 \\
22 \\
16 \\
1\end{array}$ & $\begin{array}{r}56.3 \% \\
26.9 \% \\
6.2 \% \\
5.8 \% \\
4.2 \% \\
0.6 \% \\
\end{array}$ & $\begin{array}{l}3.0 \% \\
2.7 \% \\
1.4 \% \\
1.5 \% \\
1.3 \% \\
0.6 \%\end{array}$ \\
\hline $\begin{array}{l}\text { Q14. This place is a beautiful } \\
\text { area. }(n=417)\end{array}$ & $\begin{array}{r}\text { Strongly agree } \\
\text { Somewhat agree } \\
\text { Neither agree nor disagree } \\
\text { Somewhat disagree } \\
\text { Strongly disagree } \\
\text { Don't know }\end{array}$ & $\begin{array}{r}257 \\
98 \\
33 \\
17 \\
12 \\
0\end{array}$ & $\begin{array}{r}61.1 \% \\
24.2 \% \\
8.2 \% \\
4.2 \% \\
2.3 \% \\
0.0 \% \\
\end{array}$ & $\begin{array}{l}2.9 \% \\
2.6 \% \\
1.7 \% \\
1.2 \% \\
0.8 \% \\
0.0 \% \\
\end{array}$ \\
\hline $\begin{array}{l}\text { Q15. Nature is unspoiled in this } \\
\text { place. }(n=418)\end{array}$ & $\begin{array}{r}\text { Strongly agree } \\
\text { Somewhat agree } \\
\text { Neither agree nor disagree } \\
\text { Somewhat disagree } \\
\text { Strongly disagree } \\
\text { Don't know }\end{array}$ & $\begin{array}{r}89 \\
137 \\
51 \\
82 \\
49 \\
10\end{array}$ & $\begin{array}{r}21.4 \% \\
31.7 \% \\
10.2 \% \\
22.4 \% \\
11.7 \% \\
2.7 \% \\
\end{array}$ & $\begin{array}{l}2.4 \% \\
2.7 \% \\
1.6 \% \\
2.6 \% \\
1.9 \% \\
1.0 \%\end{array}$ \\
\hline $\begin{array}{l}\text { Q16. This place is too quiet; it } \\
\text { needs to liven up a bit. } \\
\text { ( } n=419)\end{array}$ & $\begin{array}{r}\text { Strongly agree } \\
\text { Somewhat agree } \\
\text { Neither agree nor disagree } \\
\text { Somewhat disagree } \\
\text { Strongly disagree } \\
\text { Don't know }\end{array}$ & $\begin{array}{r}27 \\
29 \\
42 \\
131 \\
188 \\
2\end{array}$ & $\begin{array}{r}8.3 \% \\
7.8 \% \\
10.7 \% \\
32.0 \% \\
40.8 \% \\
0.3 \% \\
\end{array}$ & $\begin{array}{l}1.8 \% \\
1.7 \% \\
1.9 \% \\
2.8 \% \\
2.9 \% \\
0.2 \% \\
\end{array}$ \\
\hline $\begin{array}{r}\text { Q17. Do you belong to a } \\
\text { community organization, club, } \\
\text { church, or group in the area? ( } \\
=415)\end{array}$ & $\begin{array}{r}\text { Yes } \\
\text { No }\end{array}$ & $\begin{array}{l}271 \\
144\end{array}$ & $\begin{array}{l}58.5 \% \\
41.5 \%\end{array}$ & $\begin{array}{l}3.0 \% \\
3.0 \%\end{array}$ \\
\hline $\begin{array}{l}\text { Q18. In the past year, did you } \\
\text { give money to a community } \\
\text { organization, located or } \\
\text { working in the area? }(n=410)\end{array}$ & $\begin{array}{r}\text { Yes } \\
\text { No }\end{array}$ & $\begin{array}{l}291 \\
119\end{array}$ & $\begin{array}{l}67.2 \% \\
32.8 \%\end{array}$ & $\begin{array}{l}2.9 \% \\
2.9 \%\end{array}$ \\
\hline $\begin{array}{r}\text { Q19. Are you involved in any } \\
\text { local volunteer work in the } \\
\text { area? }(n=416)\end{array}$ & $\begin{array}{r}\text { Yes } \\
\text { No }\end{array}$ & $\begin{array}{l}192 \\
224\end{array}$ & $\begin{array}{l}44.6 \% \\
55.4 \%\end{array}$ & $\begin{array}{l}2.9 \% \\
2.9 \%\end{array}$ \\
\hline & & & & \\
\hline
\end{tabular}




\begin{tabular}{|c|c|c|c|c|}
\hline Question & Responses & $\begin{array}{c}\text { Raw } \\
\text { Frequency }\end{array}$ & $\begin{array}{c}\text { Weighed } \\
\text { Percent }\end{array}$ & $\begin{array}{l}\text { Std. } \\
\text { Error }\end{array}$ \\
\hline $\begin{array}{r}\text { Q20. Do you consider yourself } \\
\text { to live in rural, urban, or } \\
\text { suburban area? } \\
(n=418)\end{array}$ & $\begin{array}{r}\text { Rural } \\
\text { Urban } \\
\text { Suburban } \\
\text { Refused } \\
\end{array}$ & $\begin{array}{r}155 \\
98 \\
163 \\
2\end{array}$ & $\begin{array}{r}35.9 \% \\
26.4 \% \\
37.2 \% \\
0.6 \% \\
\end{array}$ & $\begin{array}{l}2.8 \% \\
2.7 \% \\
2.8 \% \\
0.4 \%\end{array}$ \\
\hline $\begin{array}{l}\text { Q21. What is your occupation? } \\
\qquad(\mathrm{n}=413)\end{array}$ & $\begin{array}{r}\text { Agriculture, forestry, fishing, mining } \\
\text { Construction } \\
\text { Manufacturing } \\
\text { Wholesale trade } \\
\text { Retail trade } \\
\text { Finance, real estate, insurance } \\
\text { Information [publishers, television, radio, Web, } \\
\text { telecommunications, libraries, software, etc] } \\
\text { management } \\
\text { Professional, scientific, management, admin, waste } \\
\text { Education (all levels) } \\
\text { Health care and social assistance [includes all doctors, } \\
\text { home health care providers, social services] } \\
\text { Arts, entertainment, recreation, accommodation, or food } \\
\text { services [artists, museums, hotels, restaurants] } \\
\text { Other services [inc. auto repair, religious institutions, } \\
\text { nonprofits, dry cleaning, funeral homes] } \\
\text { Public administration [courts, police, fire, city/state/Federal } \\
\text { workers] } \\
\text { Not sure (specify occupation) } \\
\text { Retired }\end{array}$ & $\begin{array}{r}10 \\
11 \\
7 \\
2 \\
21 \\
4 \\
\\
18 \\
29 \\
18 \\
31 \\
8 \\
\\
22 \\
14 \\
91 \\
127\end{array}$ & $\begin{array}{l}3.6 \% \\
3.3 \% \\
1.8 \% \\
0.7 \% \\
4.6 \% \\
1.5 \% \\
\\
5.3 \% \\
7.6 \% \\
\\
4.0 \% \\
7.8 \% \\
\\
2.1 \% \\
\\
5.2 \% \\
\\
3.9 \% \\
22.8 \% \\
25.9 \% \\
\end{array}$ & $\begin{array}{l}1.3 \% \\
1.2 \% \\
0.8 \% \\
0.6 \% \\
1.2 \% \\
0.9 \% \\
\\
1.4 \% \\
1.7 \% \\
1.1 \% \\
1.6 \% \\
\\
0.9 \% \\
1.3 \% \\
\\
1.3 \% \\
2.5 \% \\
2.4 \%\end{array}$ \\
\hline $\begin{array}{l}\text { How many years have you lived } \\
\text { in your current home? }(n=413)\end{array}$ & $\begin{array}{r}\text { Less than three } \\
\text { Three to seven } \\
\text { Eight to fourteen } \\
\text { Fifteen to nineteen } \\
\text { More than twenty }\end{array}$ & $\begin{array}{r}103 \\
91 \\
77 \\
32 \\
110 \\
\end{array}$ & $\begin{array}{r}31.1 \% \\
23.8 \% \\
17.6 \% \\
6.2 \% \\
21.3 \% \\
\end{array}$ & $\begin{array}{l}2.9 \% \\
2.6 \% \\
2.2 \% \\
1.3 \% \\
2.2 \% \\
\end{array}$ \\
\hline $\begin{array}{r}\text { Q22. What is your current } \\
\text { housing arrangement? } \\
\qquad(\mathrm{n}=416)\end{array}$ & $\begin{array}{r}\text { I am a home owner } \\
\text { I rent } \\
\text { I live with another person (not a spouse) who pays the cost } \\
\text { of my housing } \\
\text { I live in a dorm, nursing home, or other group facility } \\
\text { Other (specify) }\end{array}$ & $\begin{array}{r}294 \\
90 \\
21 \\
6 \\
5\end{array}$ & $\begin{array}{r}63.2 \% \\
29.0 \% \\
4.8 \% \\
2.1 \% \\
0.8 \% \\
\end{array}$ & $\begin{array}{l}3.0 \% \\
2.9 \% \\
1.2 \% \\
0.9 \% \\
0.4 \% \\
\end{array}$ \\
\hline $\begin{array}{r}\text { Q28. What is the highest level } \\
\text { of education that you have } \\
\text { completed? } \\
(n=416)\end{array}$ & $\begin{array}{r}\text { 8th grade or less } \\
\text { 9th-12th grade, no diploma } \\
\text { High school graduate (includes GED) } \\
\text { Some college, no degree } \\
\text { Associate's degree } \\
\text { Bachelor's degree } \\
\text { Graduate or professional degree }\end{array}$ & $\begin{array}{r}7 \\
15 \\
74 \\
76 \\
43 \\
113 \\
88\end{array}$ & $\begin{array}{r}2.3 \% \\
5.1 \% \\
18.1 \% \\
17.0 \% \\
8.7 \% \\
27.4 \% \\
21.7 \%\end{array}$ & $\begin{array}{l}0.9 \% \\
1.4 \% \\
2.3 \% \\
2.2 \% \\
1.5 \% \\
2.7 \% \\
2.5 \%\end{array}$ \\
\hline
\end{tabular}




\begin{tabular}{|c|c|c|c|c|}
\hline Question & Responses & $\begin{array}{c}\text { Raw } \\
\text { Frequency }\end{array}$ & $\begin{array}{c}\text { Weighted } \\
\text { Percent }\end{array}$ & $\begin{array}{l}\text { Std. } \\
\text { Error }\end{array}$ \\
\hline $\begin{array}{r}\text { Q50. Race } \\
(n=430)\end{array}$ & $\begin{array}{r}\text { African American } \\
\text { American Indian } \\
\text { Asian } \\
\text { Hispanic/Latino/a } \\
\text { White } \\
\text { Other } \\
\end{array}$ & $\begin{array}{r}24 \\
13 \\
9 \\
29 \\
327 \\
15 \\
\end{array}$ & $\begin{array}{r}7.3 \% \\
2.0 \% \\
1.8 \% \\
9.0 \% \\
73.1 \% \\
4.0 \% \\
\end{array}$ & $\begin{array}{l}1.7 \% \\
0.6 \% \\
0.7 \% \\
1.9 \% \\
2.7 \% \\
1.2 \% \\
\end{array}$ \\
\hline $\begin{array}{r}\text { Q51. In general, would you } \\
\text { describe your political views } \\
\text { as.. }(n=387) .\end{array}$ & $\begin{array}{r}\text { Very conservative } \\
\text { Conservative } \\
\text { Moderate } \\
\text { Liberal } \\
\text { Very liberal } \\
\end{array}$ & $\begin{array}{r}42 \\
102 \\
145 \\
71 \\
27\end{array}$ & $\begin{array}{r}11.0 \% \\
23.6 \% \\
36.6 \% \\
22.4 \% \\
6.3 \% \\
\end{array}$ & $\begin{array}{l}1.9 \% \\
2.5 \% \\
3.0 \% \\
2.7 \% \\
1.4 \%\end{array}$ \\
\hline $\begin{array}{r}\text { Q52. In politics today, do you } \\
\text { consider yourself a } \\
\text { Republican, Democrat, or } \\
\text { Independent? }(\mathrm{n}=398)\end{array}$ & $\begin{array}{r}\text { Republican } \\
\text { Democrat } \\
\text { Independent/no preference/other } \\
\text { Don't know }\end{array}$ & $\begin{array}{r}111 \\
124 \\
153 \\
10 \\
\end{array}$ & $\begin{array}{r}26.3 \% \\
32.1 \% \\
39.5 \% \\
2.1 \% \\
\end{array}$ & $\begin{array}{l}2.6 \% \\
2.9 \% \\
3.0 \% \\
0.8 \% \\
\end{array}$ \\
\hline $\begin{array}{r}\text { Q52. Approximately how much } \\
\text { did you pay for electricity last } \\
\text { month? } \\
(\mathrm{n}=404)\end{array}$ & $\begin{array}{r}\text { Under } \$ 25 \\
\$ 25-\$ 50 \\
\$ 50-\$ 75 \\
\$ 75-\$ 100 \\
\$ 100-\$ 125 \\
\$ 125-\$ 150 \\
\$ 150-\$ 200 \\
\text { Over } \$ 200\end{array}$ & $\begin{array}{l}67 \\
35 \\
49 \\
36 \\
54 \\
32 \\
52 \\
79\end{array}$ & $\begin{array}{r}17.9 \% \\
11.2 \% \\
12.5 \% \\
7.8 \% \\
14.1 \% \\
7.6 \% \\
12.5 \% \\
16.4 \%\end{array}$ & $\begin{array}{l}2.4 \% \\
2.1 \% \\
2.0 \% \\
1.5 \% \\
2.2 \% \\
1.6 \% \\
2.0 \% \\
2.0 \%\end{array}$ \\
\hline $\begin{array}{r}\text { Income } \\
(\mathrm{n}=363)\end{array}$ & $\begin{array}{r}\text { Less than } \$ 24,999 \\
\text { Between } \$ 25,000 \text { and } \$ 49,999 \\
\text { Between } \$ 50,000 \text { and } \$ 74,999 \\
\text { Between } \$ 75,000 \text { and } \$ 99,999 \\
\text { More than } \$ 100,000 \\
\end{array}$ & $\begin{array}{l}54 \\
85 \\
88 \\
45 \\
91\end{array}$ & $\begin{array}{l}16.1 \% \\
26.9 \% \\
23.4 \% \\
10.6 \% \\
22.8 \% \\
\end{array}$ & $\begin{array}{l}2.4 \% \\
2.9 \% \\
2.7 \% \\
1.8 \% \\
2.6 \%\end{array}$ \\
\hline $\begin{array}{l}\text { How many years have you lived } \\
\text { in this area? }(n=410)\end{array}$ & $\begin{array}{r}\text { Less than five } \\
\text { Five to nine } \\
\text { Ten to fourteen } \\
\text { Fifteen to nineteen } \\
\text { More than twenty }\end{array}$ & $\begin{array}{r}65 \\
44 \\
53 \\
27 \\
221 \\
\end{array}$ & $\begin{array}{r}21.5 \% \\
12.5 \% \\
11.7 \% \\
6.4 \% \\
48.0 \%\end{array}$ & $\begin{array}{l}2.7 \% \\
2.1 \% \\
1.8 \% \\
1.4 \% \\
3.0 \%\end{array}$ \\
\hline Gender $(n=417)$ & $\begin{array}{r}\text { Male } \\
\text { Female }\end{array}$ & $\begin{array}{l}287 \\
354 \\
\end{array}$ & $\begin{array}{l}48.7 \% \\
51.3 \% \\
\end{array}$ & $\begin{array}{l}2.3 \% \\
2.3 \% \\
\end{array}$ \\
\hline $\begin{array}{r}\text { Language } \\
(n=430)\end{array}$ & $\begin{array}{c}\text { English } \\
\text { Spanish }\end{array}$ & $\begin{array}{r}420 \\
10 \\
\end{array}$ & $\begin{array}{r}96.7 \% \\
3.3 \% \\
\end{array}$ & $\begin{array}{l}1.2 \% \\
1.2 \%\end{array}$ \\
\hline $\begin{array}{r}\text { Age } \\
(n=411)\end{array}$ & $\begin{array}{r}18-34 \\
35-44 \\
45-54 \\
55-64 \\
65 \text { and older }\end{array}$ & $\begin{array}{r}73 \\
43 \\
77 \\
100 \\
118\end{array}$ & $\begin{array}{l}24.8 \% \\
11.9 \% \\
17.2 \% \\
23.3 \% \\
22.8 \%\end{array}$ & $\begin{array}{l}2.8 \% \\
2.1 \% \\
2.2 \% \\
2.5 \% \\
2.2 \%\end{array}$ \\
\hline
\end{tabular}

